\title{
Vertical strain partitioning in hot Variscan crust: Syn-convergence escape of the Pyrenees in the Iberian-Armorican syntax
}

\author{
Bryan Cochelin $^{1,2}$, Dominique Chardon ${ }^{1,3,4, *}$, Yoann Denèle ${ }^{1}$, Charles Gumiaux ${ }^{5}$ and Benjamin Le \\ Bayon $^{2}$ \\ ${ }^{1}$ Géosciences Environnement Toulouse, Université de Toulouse, CNRS, IRD, UPS, CNES, 31400 Toulouse, France \\ 2 BRGM DGR/GSO, BP 36009, 45060 Orléans, France \\ 3 IRD, 01 BP 182, Ouagadougou 01, Burkina Faso \\ ${ }_{5}^{4}$ Département des Sciences de la Terre, Université Ouaga I Professeur Joseph Ki-Zerbo, BP 7021, Ouagadougou, Burkina Faso \\ ${ }^{5}$ Université Orléans, CNRS, BRGM, ISTO, UMR 7327, 1A Rue de la Ferollerie, 45071 Orléans, France
}

\begin{abstract}
A new structural map of the Paleozoic crust of the Pyrenees based on an extensive compilation and new kinematic data allows for the evaluation of the mechanical coupling between the upper and lower crust of the abnormally hot foreland of the Variscan orogen of SW Europe. We document partitioning between coeval lower crustal lateral flow and upper crustal thickening between 310 and $290 \mathrm{Ma}$ under an overall dextral transpressive regime. Partitioning also involved syn-convergence transtensional gneiss domes emplacement during this period. Late orogen-normal shortening of the domes and strain localization in steep crustal-scale transpressive shear zones reflects increasing coupling between the lower crust and the upper crust. The combination of dextral transpression and eastward flow in the Pyrenees results from the shortening and lateral escape of a hot buoyant crust along the inner northern limb of the closing Cantabrian orocline at the core of the Iberian-Armorican arc between ca. 305 and $295 \mathrm{Ma}$. Delamination or thermal erosion of the lithosphere enhanced orocline closure and explains (1) the switch from crust- to mantlederived magmatism in the Iberian-Armorican arc and (2) the abnormally hot and soft character of the Pyrenean crust that escaped the closing syntax.
\end{abstract}

Keywords: Variscan / Pyrenees / syntax / orocline / gneiss dome / transpression / hot orogen

Résumé - Partitionnement vertical de la déformation dans la croûte varisque chaude : échappement des Pyrénées de la syntaxe ibéro-armoricaine. Une nouvelle carte structurale harmonisée et une série de coupes de la croûte paléozoïque des Pyrénées sont présentées sur la base d'une compilation et de nouvelles observations de terrain. Cette carte permet d'évaluer les modalités du couplage mécanique entre la croûte supérieure et la croûte inférieure de l'avant-pays anormalement chaud de l'orogène varisque. La croûte inférieure a flué latéralement pendant l'épaississement de la croûte supérieure dans un contexte transpressif dextre entre 310 et 290 Ma. Dans ce contexte convergent et grâce à un couplage crustal partiel, la croûte inférieure a pu être partiellement exhumée dans des dômes gneissiques transtensifs. Le serrage tardif des dômes et la localisation progressive de la déformation dans des zones de cisaillement transpressives d'ampleur régionale attestent de l'augmentation du degré de couplage entre croûtes supérieure et inférieure pendant le refroidissement régional. La combinaison de la transpression dextre et du fluage latéral de la croûte des Pyrénées résulte du raccourcissement et de l'échappement du matériau piégé dans la syntaxe ibéro-armoricaine lors de son amplification et la fermeture de l'orocline cantabrique en son cœur entre 305 et 295 Ma. L'érosion thermique ou la délamination du manteau lithosphérique a permis (1) la transition entre un magmatisme crustal et un magmatisme mantellique ou hybride dans la syntaxe et (2) la fermeture de l'orocline et l'échappement contemporain du matériel pyrénéen chaud qu'elle contenait.

Mots clés : Varisque / Pyrénées / syntaxe / orocline / dôme gneissique / transpression / orogène chaud

\footnotetext{
*Corresponding author: dominique.chardon@ird.fr
} 


\section{Introduction}

In convergent or divergent zones, deformation is unevenly distributed within a given structural level and between contiguous lithospheric layers of contrasted rheology (Grocott et al., 2004). Under brittle conditions, strain is partitioned between strike-slip faults and normal or reverse faults for transtension and transpression, respectively (Tikoff and Teyssier, 1994; Allen et al., 1998; Dokka et al., 1998). Under plastic or ductile regime, strain may be partitioned among shear zones with variable orientations and slip, on the one hand, and lower strain domains of homogeneous strain, on another hand (Gapais et al., 1987; Holdsworth and Strachan, 1991; Holdsworth et al., 2002). The upper and lower crusts may be mechanically coupled to various degrees, in such a way that deformation is differently expressed in each layer while partial structural continuity and kinematic compatibility are maintained between them. The transition between these two crustal layers defines an attachment zone (Tikoff et al., 2002, 2004). In case of complete decoupling, the attachment becomes a décollement or a detachment. In mature orogens, mechanical coupling between crustal layers is influenced by the fact that the lower crust is hot, partially molten and therefore weak, buoyant and prompt to flow under its own weight (Vanderhaeghe and Teyssier, 2001; Chardon et al., 2009). Under convergence, lateral flow of the weak lower crust interferes with thickening of the upper crust across the attachment, which also acts as a filter absorbing downward thickening of the upper crust, upward flow of the lower crust in gneiss domes, and ascent of lower crustal melts (Chardon et al., 2009, 2011; Bajolet et al., 2015). Under synconvergence lateral flow regimes, lower crust exhumation in gneiss domes is not yet well understood. Some models of gneiss domes formation suggest that decoupling is necessary to form such gneiss domes (the channel flow hypothesis e.g., Rey et al., 2010) but are limited to two dimensions. Other models stress that transcurrent faulting is instrumental to enhance lower crust exhumation (e.g., Le Pourhiet et al., 2012; Roger et al., 2015; Rey et al., 2017) but are imposed on releasing fault steps under purely strike-slip conditions and do not integrate convergence-driven crustal shortening.

The present study explores strain partitioning between the upper crust and the lower crust and its interplay with exhumation of the lower crust during the convergence undergone by the Variscan orogen of SW Europe during latest Carboniferous and Permian times (ca. 320-290 Ma). The chosen case study is the Paleozoic crust exposed in the Pyrenees, which recorded HT-LP regional metamorphism and exposes the relationships between portions of the hot mid-crust and the deep upper crust (Zwart, 1986). The Pyrenees belong to the southern foreland basin of the Variscan orogen that accumulated Carboniferous flysch sediments (Engel, 1984) and that is enclosed in a syntax called the Iberian-Armorican Arc (Matte, 1986; Fig. 1). HT-LP metamorphism of the Pyrenees in a foreland context far from the southernmost HP metamorphic relicts of the Montagne Noire (Fig. 1) appears as an anomaly in the orogen. The proximity of the Pyrenees with the Cantabrian orocline (Fig. 1) that was bent at the core of the syntax between 305 and $295 \mathrm{Ma}$ (Van der Voo, 2004; Weil et al., 2010; Pastor-Galán et al., 2011, 2016; Gutiérrez-Alonso et al., 2012) further suggests a link between metamorphism, plutonism and deformation in the Pyrenees (ca.
320-290 Ma; see below) and orocline closure (Denèle et al., 2014). The second aim of our work is therefore to replace the structural pattern of the Pyrenean crust within the evolving kinematic frame of the Variscan orogen, with an emphasis on the closure of the Cantabrian orocline in an abnormally hot foreland setting. The present study is based on an extensive compilation of fabric data and new structural observations at the scale of the Pyrenees that allowed building an integrated regional structural map. A 3D crustal coupling model is proposed to explain the interplay of lower crustal flow and upper crustal transpression as well as oblique (transtensional) extension allowing for the exhumation of gneiss domes under convergence. We show how such a $3 \mathrm{D}$ orogenic flow mode recorded the closure of the Cantabrian orocline in a context of hot and thin lithosphere.

\section{Geological setting}

\subsection{Variscan belt of Southwestern Europe}

The Variscan belt of Western Europe recorded convergence and collisional mountain building between the Avalonia microcontinent and the northern margin of Gondwanaland from the Late Devonian to the Latest Carboniferous. Convergence led to the subduction and closure of various oceanic domains during the Devonian, HP-LT nappe stacking and exhumation up to ca. $360 \mathrm{Ma}$ (e.g., Paquette et al., 1989; Bosse et al., 2000; Ordóñez Casado et al., 2001; Rodríguez et al., 2003; Roger and Matte, 2005; Giacomini et al., 2006; Ballèvre et al., 2009, 2014; Faure et al., 2008, 2009; Abati et al., 2010). Pervasive partial melting and late- to post-orogenic extension affected the hinterland of the orogen from ca. $340 \mathrm{Ma}$ to $290 \mathrm{Ma}$ (Burg et al., 1994; Faure, 1995; Fernández-Suárez et al., 2000; Faure et al., 2009; Gutiérrez-Alonso et al., 2011a; Rubio Pascual et al., 2013; Lardeaux et al., 2014; Gapais et al., 2015). The orogen has undergone reorganization from the late Carboniferous to the early Permian by the amplification of syntaxes and the activation of major transcurrent fault systems (Arthaud and Matte, 1975, 1977; Matte and Ribeiro, 1975; Matte, 1986; Burg et al., 1994; Martínez-Catalán, 2011; Gutiérrez-Alonso et al., 2012; Dias et al., 2016). Lateral mass transfers due to syntax amplification and strike-slip movements have exerted a major control on the pattern of syn-convergence extension (330-305 Ma), whereas the transcurrent faults have favored large-scale partitioning of post-orogenic extension (305-260 Ma) over the collapsing orogen (Burg et al., 1994; Faure, 1995; Gébelin et al., 2007, 2009; Gapais et al., 2015). The Iberian-Armorican arc (e.g., Ballèvre et al., 2014; Fig. 1) is a Variscan syntax. Recent works have allowed documenting bending of the Cantabrian orocline at its core between 305 and $295 \mathrm{Ma}$ (Weil et al., 2010). The Pyrenees belong to the northern inner limb of the orocline (Martínez-Catalán, 1990).

\subsection{Variscan Pyrenees: geological outline and earlier works}

The present day Pyrenees form a $\mathrm{N} 100^{\circ} \mathrm{E}$ trending mountain belt (Fig. 2) that results from the interactions and ultimate collision between the Iberian and Eurasian plates, which took place from the late Cretaceous to the Paleogene (Choukroune, 1992). During convergence, Mesozoic series and their Paleozoic substrate have been shortened to form an 


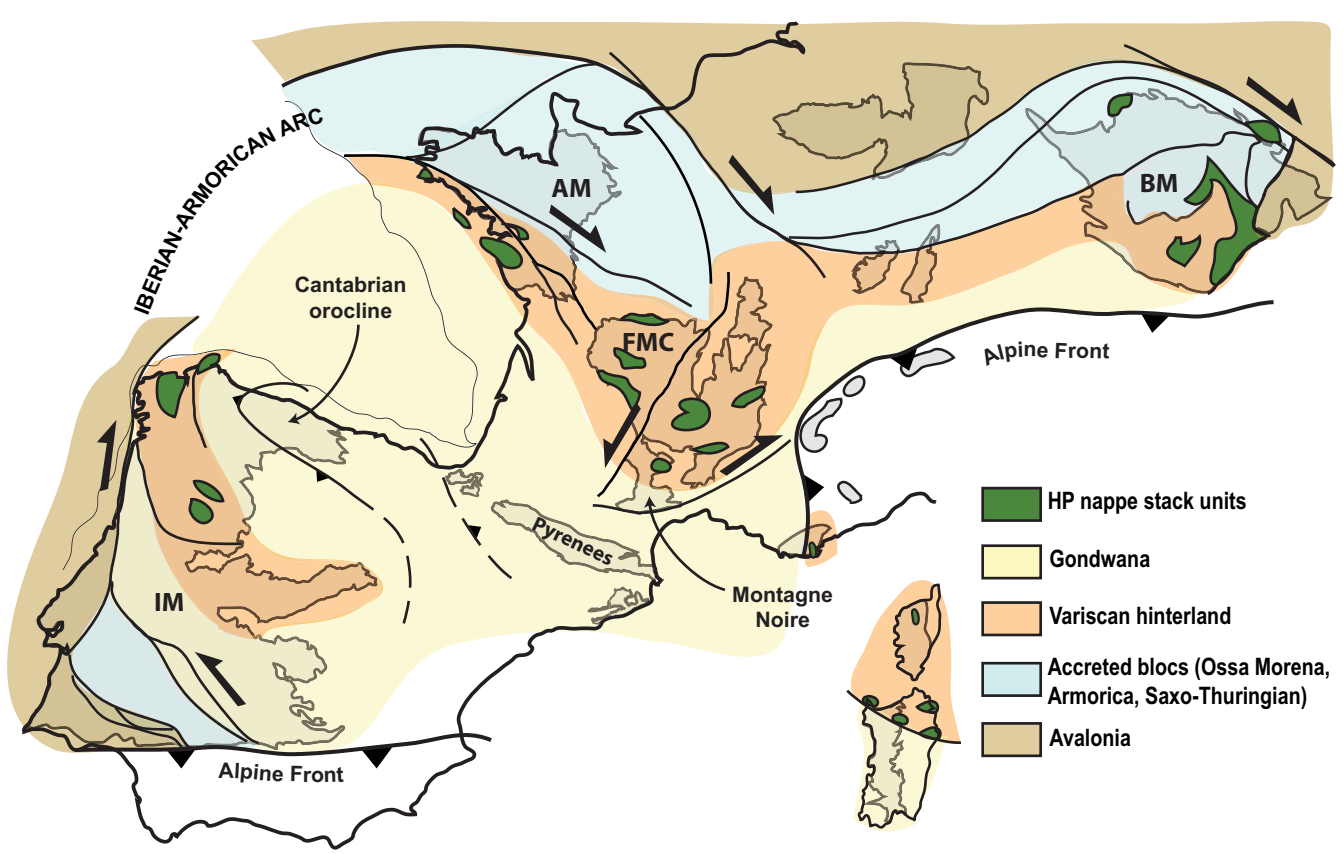

Fig. 1. Sketch structural map of the Variscan belt of Europe showing the main outcrops of Pre-Mesozoic basement (in grey). Iberia and the Pyrenees as well as Sardinia and Corsica are shown in their current position. AM: Armorican Massif; BM: Bohemian Massif; FMC: French Massif Central; IM: Iberian Massif.

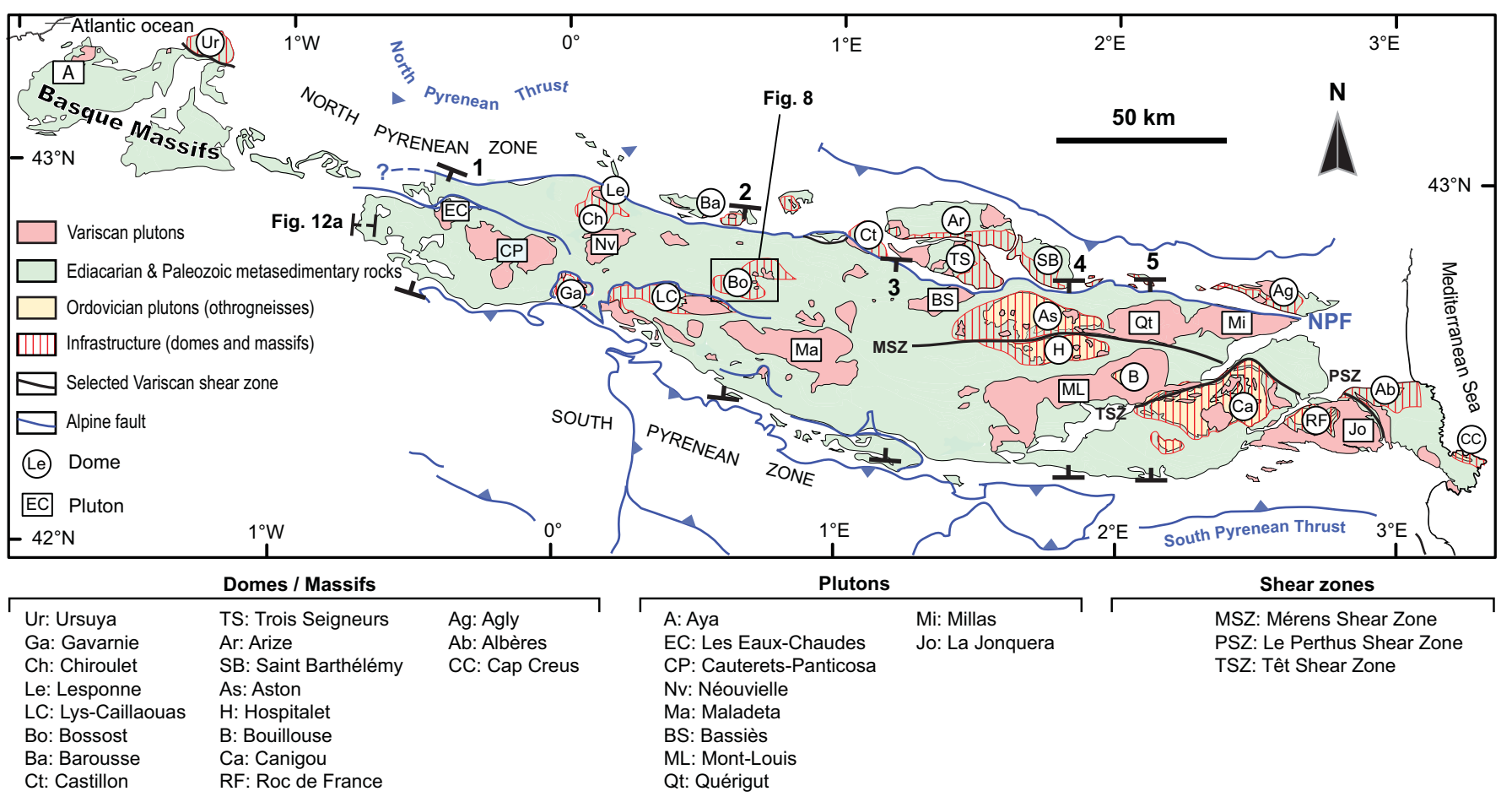

Fig. 2. Sketch map of the Paleozoic crust of the Pyrenees showing the location and name of the geological features discussed in the text. Domes and plutons are listed from West to East. Locations of the cross-sections of Figure 4 (labeled 1 to 5) and that of Figure 12a are shown.

asymmetric doubly verging orogenic prism (Choukroune et al., 1989). Paleozoic basement outcrops are found in two main structural domains separated by the North Pyrenean Fault (Fig. 2). The Axial Zone (south of the fault) forms the uplifted core of the orogen and represents the largest continuous basement outcrop, whereas the Basque and North Pyrenean massifs are smaller basement units emerging from their Mesozoic cover North of the fault (Fig. 2). The basement preserves ubiquitous Variscan structures, penetrative strain and metamorphic patterns that have only locally been modified by Meso-Cenozoic faulting and block tilting (Carreras and Debat, 1996; Carreras and Druguet, 2014). 
The Paleozoic crust of the Pyrenees is characterized by a strong structural contrast between an upper crustal level, called the superstructure, and the roof of a lower-crustal level outcropping in metamorphic domes, called the infrastructure (de Sitter and Zwart, 1960; Zwart, 1979; Carreras and Capella, 1994). The superstructure is made of low-grade Ordovician to Carboniferous metasedimentary rocks. They are intruded by large plutons of calc-alkaline affinity comprising gabbros, tonalites, granodiorites and granites of mantle or hybrid sources (Guitard et al., 1984; Debon et al., 1996; Roberts et al., 2000). The infrastructure has undergone HT-LP metamorphism (Guitard et al., 1996). It comprises Ediacarian-early Cambrian paragneisses hosting Ordovician granites (470$450 \mathrm{Ma}$ ) turned into orthogneiss sheets, as well as Ordovician micaschists and paragneisses (Carreras and Druguet, 2014; Denèle et al., 2014, and references therein). Magmatic rocks of the infrastructure are crustally derived peraluminous granites (mostly sills) and associated migmatites, as well as kilometerscale sills of diorites and gabbros. The transition between the shallow fabrics of the infrastructure and the steep fabrics of the superstructure roughly coincides with the Andalusite isograd that underlines the map shape of the domes (Guitard et al., 1996; Debon and Guitard, 1996, e.g., Fig. 2). Attenuation of the isograds at the roof of the infrastructure results in a strong field metamorphic gradient (Zwart, 1979; Wickham and Oxburgh, 1985, 1986; Van den Eeckhout and Zwart, 1988; Paquet and Mansy, 1991; de Saint-Blanquat, 1993; Guitard et al., 1996; Vilà et al., 2007; Mezger and Régnier, 2016). Clockwise PTt paths in the infrastructure have been documented from peak pressures of ca. $4.5 \mathrm{~kb}$ with significant heating during decompression and later cooling along a steep geotherm (Mezger and Passchier, 2003; Mezger et al., 2004; Mezger, 2005; Vilà et al., 2007). Recently, Aguilar et al. (2015) reported metamorphic relicts suggestive of an early hightemperature peak pressure of $7.5 \mathrm{Kbar}$ in the Roc the France dome (Fig. 2). Pre-main cleavage, folds and thrust faults have been reported from the superstructure (Mey, 1967, 1968; Valero, 1974; Müller and Roger, 1977; Zwart, 1986; Speksnijder, 1987; Carreras and Capella, 1994; Matte, 2002). Pre-main cleavage recumbent fold nappe models of the infrastructure have been proposed by Vilà et al. (2007) and Aguilar et al. (2015) for the Roc de France and Albères massifs (Fig. 2). Such models recall early interpretations of fold interference patterns emphasizing early recumbent folding ( $i$. e., Penninic style of folding) and later superimposition of upright structures (Guitard, 1964; Séguret and Proust, 1968; Guitard et al., 1984, 1998; Carreras and Capella, 1994).

Calc-akaline plutons of the superstructure yielded $\mathrm{U}-\mathrm{Pb}$ zircon ages of 310 to $290 \mathrm{Ma}$ (Aguilar et al., 2014; Denèle et al., 2014 and references therein; Druguet et al., 2014). Mezger (2010) and Mezger and Gerdes (2016) obtained $\sim 340$ Ma ages for the peraluminous granites of the Aston dome (Fig. 2) using LA-ICP-MS on zircons, at odd with ages of $\sim 306 \mathrm{Ma}$ obtained on the comparable nearby intrusions with the same method by Denèle et al. (2014). Those later authors interpreted the $\sim 340 \mathrm{Ma}$ (Visean) ages as that of an inherited crustal component in those granites instead of that of their magmatic crystallization. Esteban et al. (2015) distinguished two U-Pb zircon age groups in the Lys-Caillaouas pluton (Fig. 2) intruding the roof of the infrastructure at $307 \pm 3 \mathrm{Ma}$ and $300 \pm 2 \mathrm{Ma}$, and suggested that the first group dated metamorphism and the second pluton crystallization. Recently, Kilzi et al. (2016) obtained an age of $294 \pm 1$ Ma by LAICPMS on zircons in a mantle-derived dioritic sill hosted by migmatites of the Gavarnie massif (Fig. 2). The oldest recognized map-scale folds (Matte, 2002) affect lower to middle Pennsylvanian (318-307 Ma) flysch deposits (Delvolvé et al., 1993), providing a maximum age constraint on deformation of the superstructure. This, together with dating of synkinematic HT metamorphism, melting, plutonism and cooling from high temperature in the infrastructure and the ages of synkinematic plutons in the superstructure (310 $290 \mathrm{Ma}$ ), suggests that Variscan deformation in the Pyrenees took place between ca. 320 and $290 \mathrm{Ma}$ and between ca. 310 and 290 Ma mostly under HT-LP conditions.

Most authors agree on the fact that the steep structures and fabrics of the superstructure have recorded N-S shortening. However, the tectonic significance of the deformation patterns in the infrastructure and their spatial and temporal relationships with those of the superstructure have been debated (Carreras and Capella, 1994). Coeval deformation of the superstructure and the infrastructure under N-S shortening regime was favored by Zwart $(1979,1986)$, as well as by Soula (1982), Soula et al. (1986a, b) and Pouget (1991), who suggested diapiric emplacement of the domes. Attenuation of the isograds and associated high thermal gradient point to an extensional component of deformation at the InfrastructureSuperstructure transition (Wickham and Oxburgh, 1985, 1986; Van den Eeckhout and Zwart, 1988; de Saint-Blanquat, 1993). In the Axial Zone, extension was interpreted to have taken place before (Soula et al., 1986a), during (Mezger and Passchier, 2003) or after (Van den Eeckhout and Zwart, 1988; Vissers, 1992) shortening of the superstructure. In the eastern Pyrenees, HT deformation and magmatism have been shown to be coeval with regional-scale dextral-reverse shear zones (Carreras and Capella, 1994), in agreement with synkinematic emplacement of the plutons in the superstructure in an dextral transpressional context (Bouchez and Gleizes, 1995; Gleizes et al., 1998a, 2001, 2006; Aurejac et al., 2004; Carreras et al., 2004; Román-Berdiel et al., 2004, 2006). Recent structural analysis of the Aston, Hospitalet and Bossost domes (Fig. 2) led to models of lateral flow of the infrastructure and dome formation during regional transpression (Mezger and Passchier, 2003; Denèle et al., 2007, 2009; Mezger, 2009).

\section{Methodology and systematics of the structural markers}

We have compiled the planar and linear strain fabrics, structures (shear zones and faults) and associated kinematic criteria affecting the Paleozoic rocks of the Pyrenees. Structural data come from structural studies of the literature as well as from the French and Spanish geological maps. Evaluation and validation of the data as well as gap filling in the sampling were made through field surveys over key areas at 1873 stations, most of the kinematic measurements having been acquired for the present study. Harmonization of the data over a total of 16551 stations led to a map of the Variscan structural and kinematic patterns at the scale of the Pyrenees (Fig. 3), which is complemented by a series of regional cross-sections through the Axial Zone (Fig. 4). Given their areal extent, the Axial Zone and 


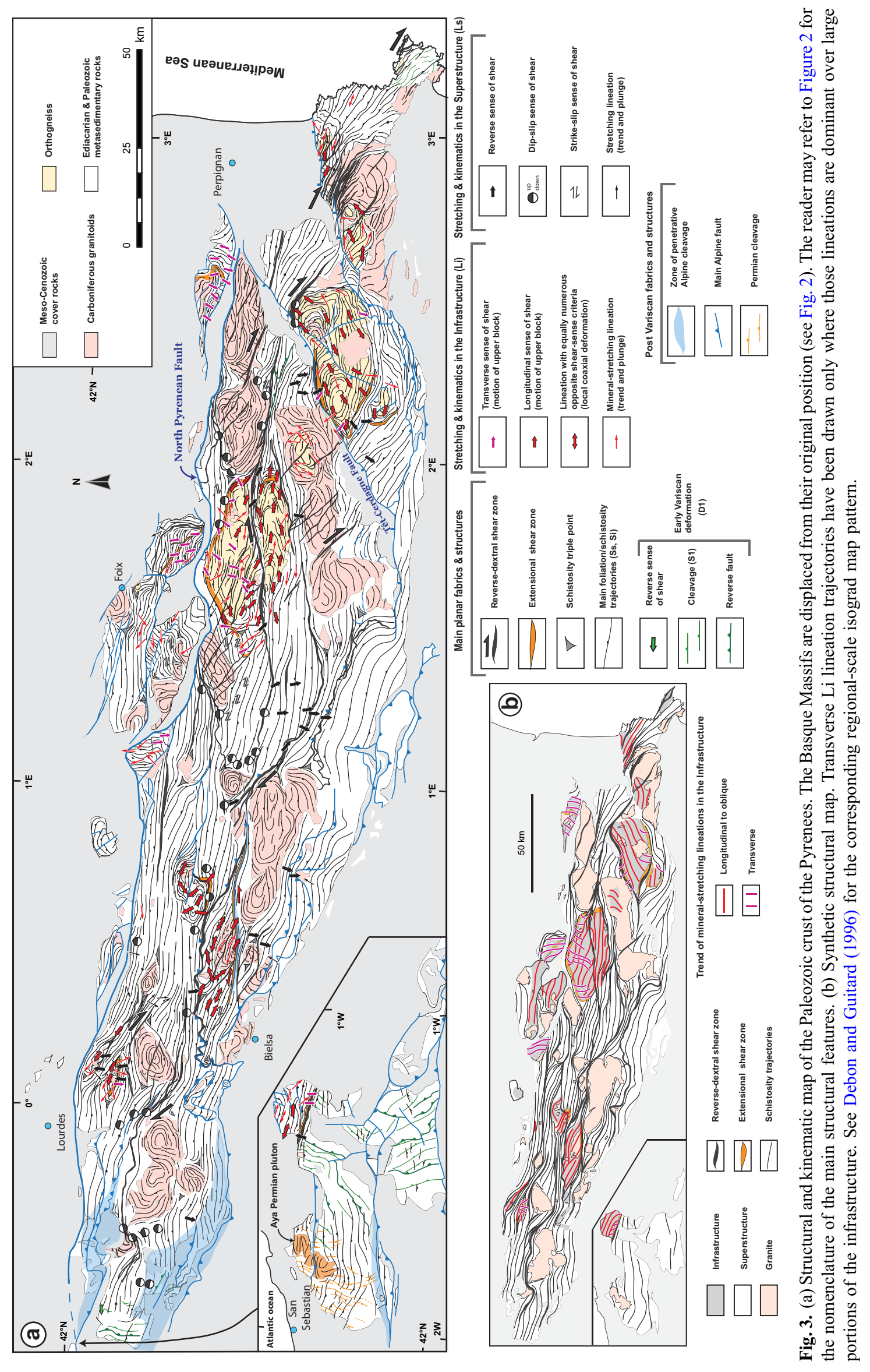




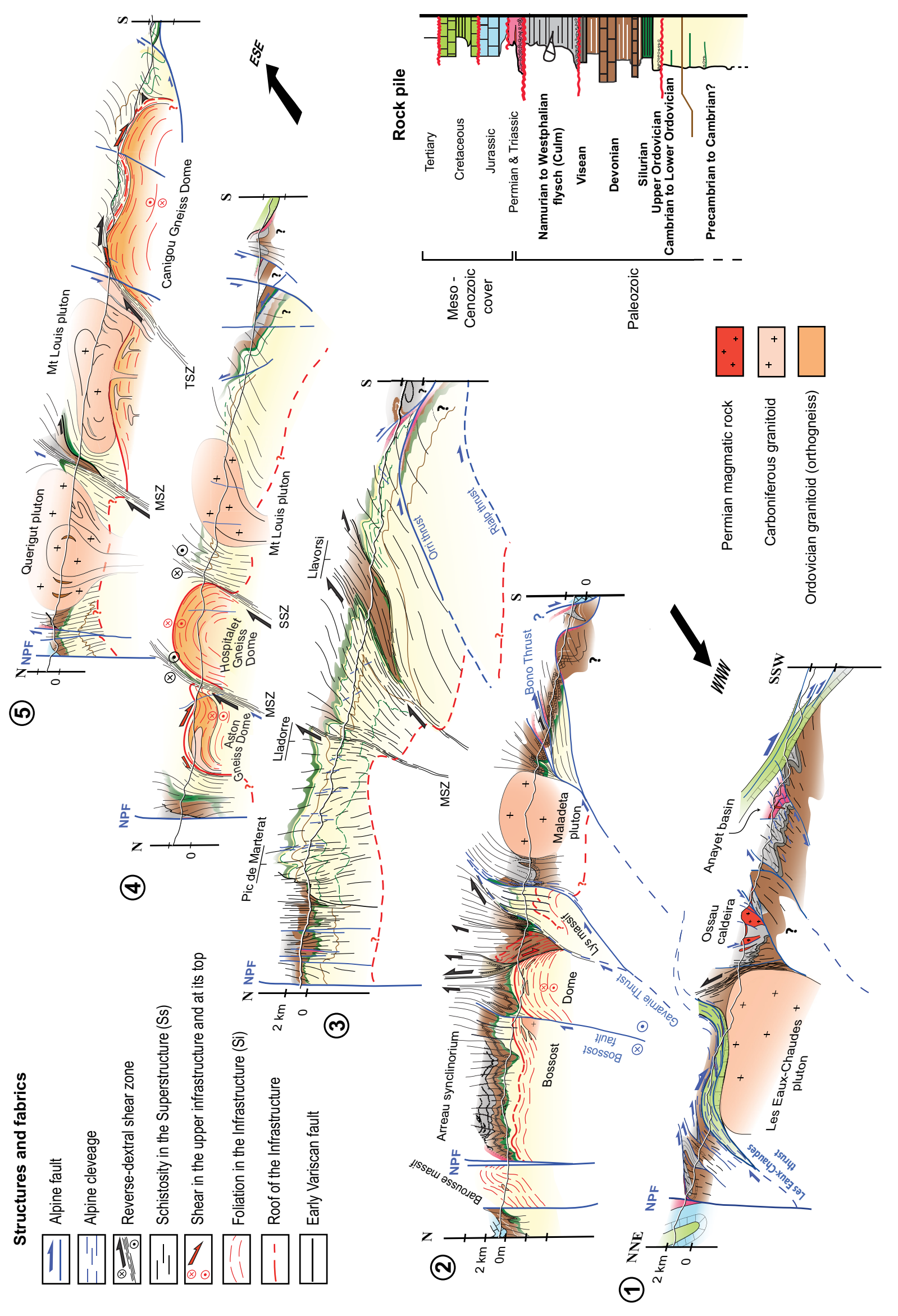

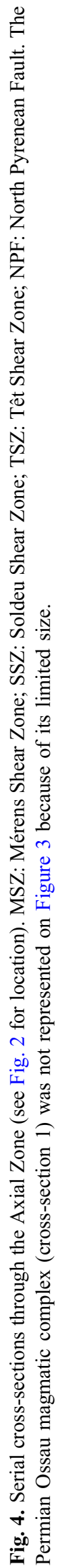




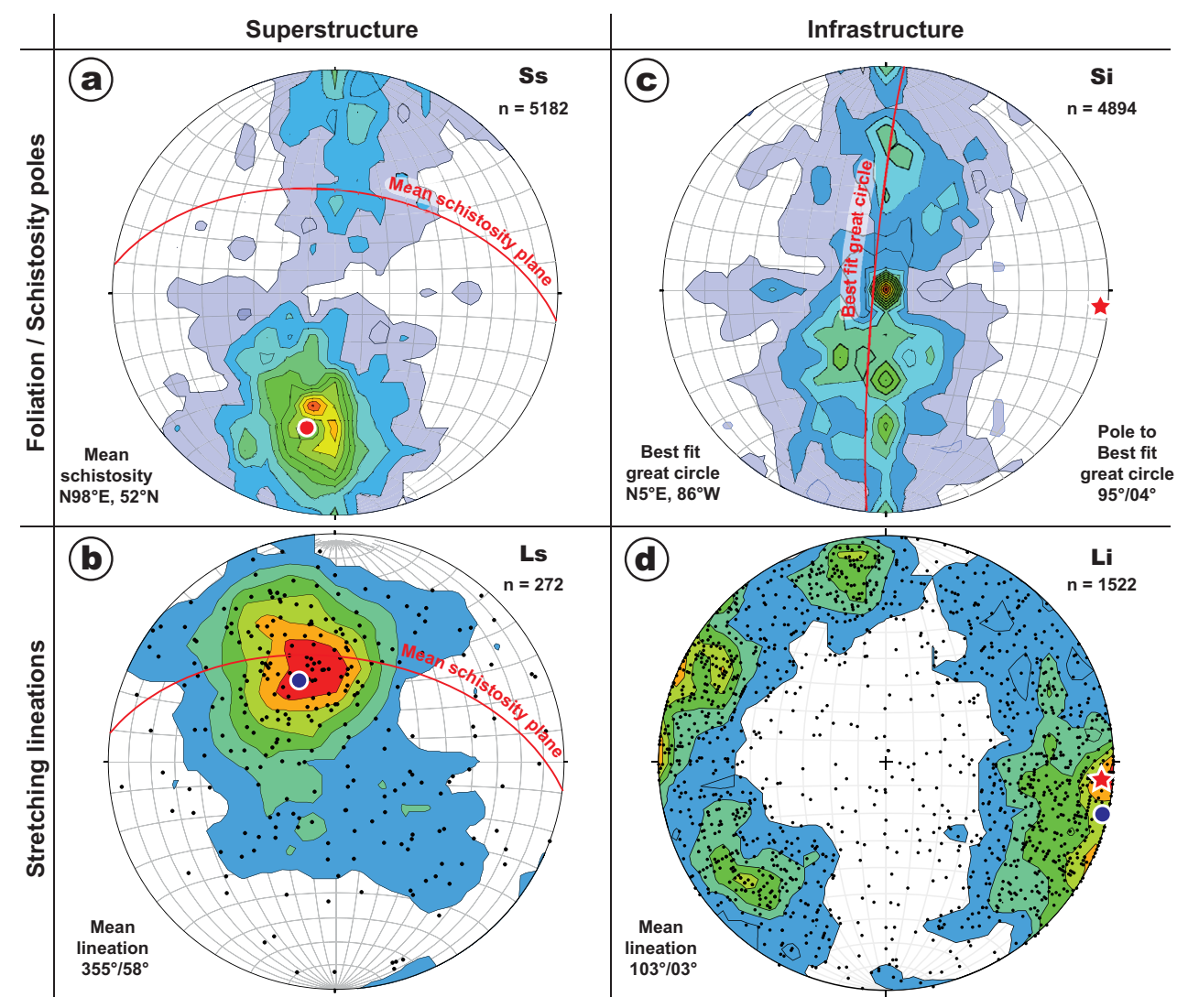

Fig. 5. Planar and linear fabric measurements from the Axial Zone. (a) Ss schistosity poles of the superstructure. (b) Ls mineral-stretching lineations of the superstructure. Ss/Ls fabrics were statistically steeper than they appear before post-Paleozoic flexure of the southern half of the Axial Zone (e.g., Fig. 4). (c) Si foliation poles of the infrastructure. (d) Li mineral-stretching lineations of the infrastructure. The red dot represents the mean pole of Ss schistosity and the red star is the pole to the planar best fit of the Si foliations, which is interpreted as the domes' hinge trend. Dark blue dots represent mean mineral-stretching lineations. Measurements are too numerous to be shown in (a) and (c). Contours are $2 \sigma$. The data include those acquired for the present study and those collected from maps and the literature (see Supplementary Material). Lower hemisphere, equal area projection.

the Basque Massifs are the focus of our work. Information on the North Pyrenean Massifs has been incorporated to the structural map mostly from the literature (Fig. 3). Analysis of the regional strain field is complemented by studies at the scale of two metamorphic domes (Bossost and Lys-Caillaouas; Fig. 2). These studies allow for the documentation of the deformation of the infrastructure, its interference patterns with the superstructure, and dome emplacement processes in greater details.

The main and ubiquitous penetrative planar fabric affecting the superstructure (called hereafter Ss) is referred to as a schistosity, which is best expressed in the dominant argilous and pelitic lithologies of the low-grade metasediments. Depending on the strain intensity and the lithology, that fabric may become a foliation in recrystallized carbonates, more commonly a fracture cleavage (in competent sandstones or carbonates) or a slaty cleavage (e.g., in calcschists). Ss is steeply dipping and is generally axial planar to macroscopic to regional-scale, steep to upright folds that range from open to isoclinal. Ss schistosity commonly bears a steep stretching and/ or mineral lineation (Ls), which is marked mostly by elongated quartz aggregates, calcite ribbons, or white mica flakes. The main penetrative planar fabric of the infrastructure is a foliation (called $\mathrm{Si}$ ) bearing a mineral-stretching lineation $(\mathrm{Li})$ defined by quartz ribbons, elongated feldspars or feldspar aggregates, fibrolitic sillimanite or aligned mica flakes or aggregates. Regional-scale schistosity (Ss) and foliation (Si) trajectories are drawn on Figure 3 together with lineation (Ls and Li) measurements, as well as regional shear zones revealed by fabric trajectories and field mapping. Foliation trajectories in the plutons were drawn on the basis of the published data. Kinematic information related to non-coaxial macroscopic deformation features such as $C^{\prime}$ shear zones and shear bands, asymmetrical boudinage and sigma clasts are also reported on Figure 3 for the infrastructure and the superstructure and the regional shear zones (see below). At a number of stations in the infrastructure, symmetrical boudinage or a comparable number of contradictory shear criteria of the same type are observed for a common stretching direction. Such a configuration is interpreted to reflect local bulk coaxial deformation (Fig. 3a).

Figure 5 synthetizes the fabric data measurements. Field illustrations of fabric and kinematic patterns are illustrated on Figures 6 and 7 for the superstructure and the infrastructure, respectively. A pre-Ss cleavage is preserved in lower strain domains of the superstructure (Figs. 2 and 3 ). This cleavage is associated with the early map-scale folds and has been mapped 

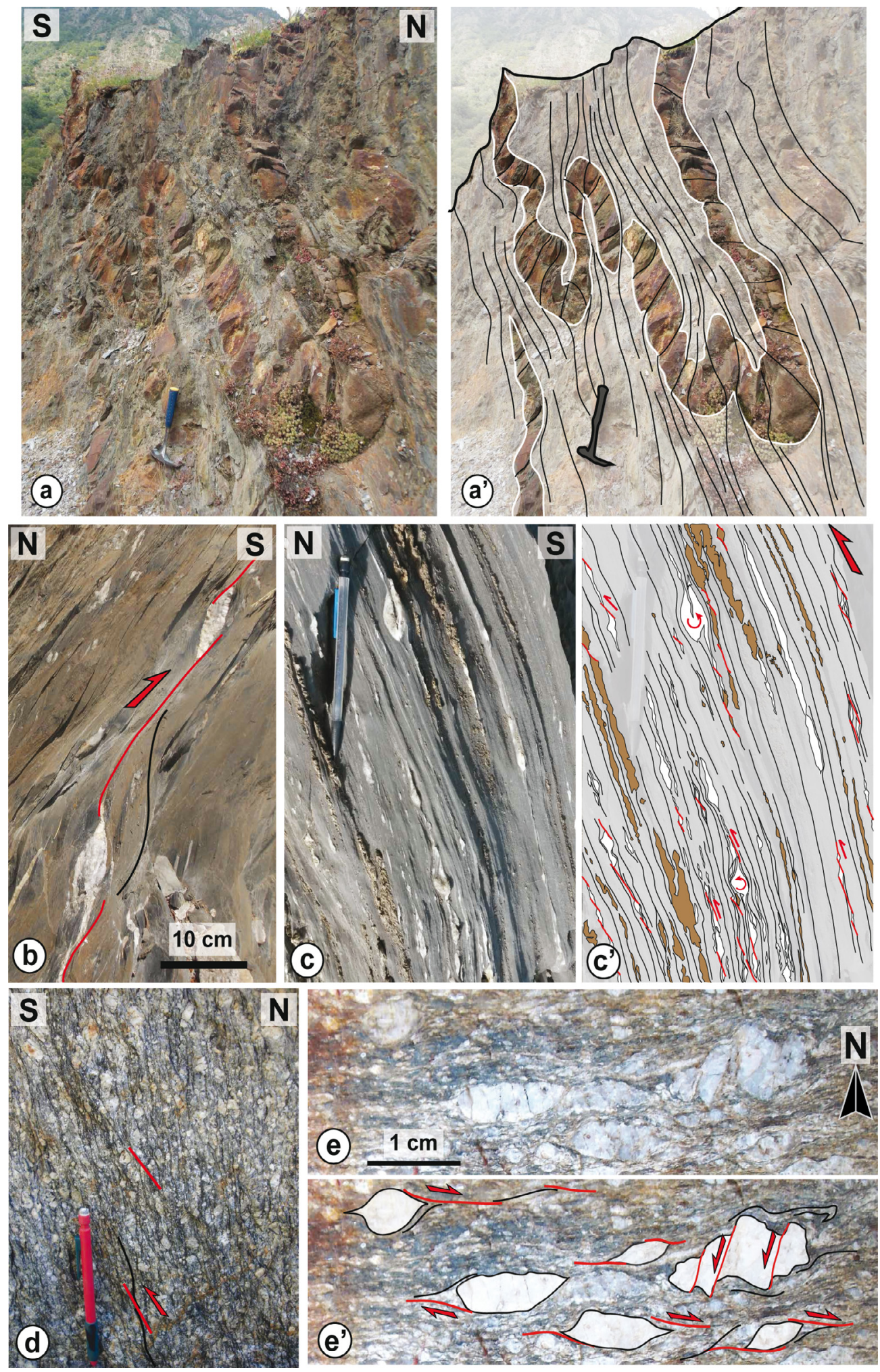

Fig. 6. Illustrations of typical structures, deformation patterns and kinematics from the Superstructure of the Axial Zone. (a)-(a') Penetrative Ss axial-planar cleavage in Cambro-Ordovician siltstones and sandstones (Southwest of the Aston dome; Fig. 2). (b) Top-to-the South asymmetrical boudinage of quartz veins in the superstructure (Cambrian to Ordovician series). (c)-(c') South-Side-Up asymmetrical boudinage of calcite veins (white) and sandstones layers (brown) within Devonian marbles (Superbagnères, southwestern flank of Bossost dome, see Fig. 8a for location). (d) Mylonitic orthogneiss from the reverse-dextral Mérens Shear Zone showing North-side-up, retrogressive (greenschist facies) $\mathrm{C}^{\prime}$ shear bands (Southern margin of the Aston dome; Fig. 2). (e)-(e') Plane view of mylonitic orthogneiss showing the dextral component of shear in the Têt-Perthus shear zone (north-eastern margin of the Canigou dome; Fig. 2). 

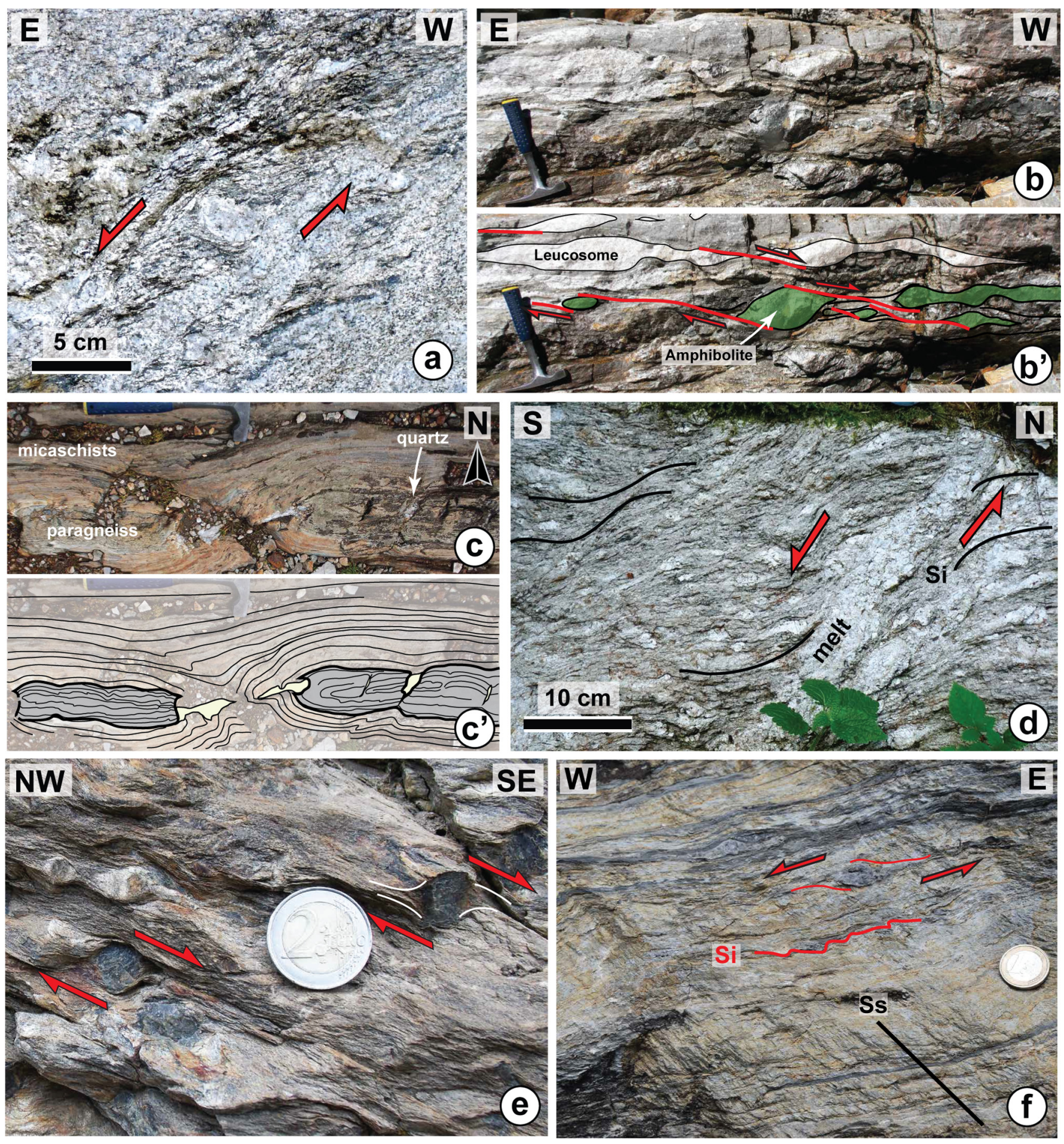

Fig. 7. Illustration of typical deformation patterns and kinematics from the Infrastructure and the attachment of the Axial Zone. (a) Syn-melt, top-to-the East shearing in diatexites of the Aston dome (Fig. 2). (b)-(b') Syn-melt top-to-the west shearing (Chiroulet dome; Fig. 2). (c)-(c') Symmetrical boudinage in andalusite-sillimanite bearing paragneisses and micaschists (Lys-Caillaouas dome; Fig. 2; location in Fig. 11a). (d) Syn-melt top-to-the South shearing at the roof of the Infrastructure (migmatitic gneisses of the Aston dome; Fig. 2). (e) Top-to-the-south-east shearing in the mylonitic pile of andalusite-staurolite bearing micaschists forming the southeastern envelop of the Bossost dome (Fig. 10). (f) Si foliation affected by top-to-the-west shearing with superimposed Ss crenulation cleavage (roof of the Canigou dome; Fig. 2). 
as S1 (Fig. 3a). In the present contribution, post-Paleozoic faults, fabrics and structures are referred to as "Alpine".

\section{Structural and kinematic analysis}

\subsection{Large-scale patterns}

Ss schistosity trajectories of the superstructure trend N90$\mathrm{N} 100^{\circ} \mathrm{E}$ and define, together with an anastomozed network of regional shear zones, the structural grain of the Axial Zone (Fig. 5a). The shear zone network mostly consists in two sets. Shear zones of the first set trend dominantly E-W, whereas those of the second set preferentially trend $\mathrm{N} 130^{\circ} \mathrm{E}$. A large part of the shear zone network had been mapped by Carreras (2001) in the eastern Axial Zone and our map shows that it extents further to the West (Fig. 3). Low-strain lens-shape domains in between the shear zones are up to $50-\mathrm{km}$ long and $10-$ to $20-\mathrm{km}$ wide and commonly host the plutons and the metamorphic domes (Fig. 3). The shear zones are steep, kilometer-thick, retrograde, amphibolite to greenschist facies mylonite zones (e.g., Carreras, 2001; Fig. 4). With the exception of the Esera Gistain shear zone South of the LysCaillaouas dome (Figs. 2 and 3; see below), the regional shear zones are systematically characterized by moderately to steeply West-plunging stretching lineations and reverse-dextral kinematics (Fig. 6d and e). The superstructure in the low-strain domains displays homogeneous deformation marked by steep rectilinear schistosity trajectories (Fig. 6a) and steeply plunging stretching lineations (Fig. 5b). Steep stretching is further attested by decameter to meter-scale $\mathrm{C}^{\prime}$ shears bearing down-dip striations with top-to-the south sense of shear throughout the southern half of the Axial Zone (Figs. 3, 5b and 6b). In the northern half of the Axial Zone, both North-side-up (mostly) and South-side-up C' shears affect the steep schistosity (Figs. 3 and $6 \mathrm{c}$ ). In the vicinity of plutons and especially in their contact aureoles, Ls stretching lineations acquire a shallower plunge and $C^{\prime}$ shear bands and shear zones have dextral senses of movement (Figs. 3 and 5 b). The plutons exhibit dominantly concentric foliation trajectories and schistosity triple points in their country rocks near their extremities (Marre, 1973; Aparicio, 1975; Messaoudi, 1990; 1998b; Debon et al., 1996). Some of the plutons are bounded by the reverse-dextral mylonitic shear zones described above (Figs. 3, 6d and e). Those pluton-bounding shear zones typically host $\mathrm{C} / \mathrm{S}$ fabrics, i.e., non-coaxial shearing features of syn-kinematic cooling granite as defined by Gapais (1989) (Têt, Perthus and Mérens shear zones; Figs. 2-4). In the southern part of the Axial Zone, from steep, Ss becomes shallowly dipping going southward (Fig. 4, sections 2-5) and the Ls stretching lineations become shallower accordingly (Fig. 5a and b). The resulting upward fan of Ss schistosity underlies the basal unconformities of the Permian or Meso-Cenozoic strata, which dip moderately $\left(40^{\circ}\right)$ to the south (Fig. 4, cross-section 3). As earlier argued by Carreras and Debat (1996), post-Paleozoic southward tilting and bending of those unconformities explain the flexuring of their substrate that produce the Ss fan. Restoration of the unconformities back to the horizontal shows that Ss was originally North-dipping around at least $60^{\circ}$ before Meso-Cenozoic deformation (Carreras and Debat, 1996). Therefore, the schistosity was consistently steep to vertical throughout the superstructure by the end of the Paleozoic.
Metamorphic domes are windows onto the infrastructure. They have an elliptical map shape, with their great axis parallel to the regional structural grain (Fig. 3). They are of two types. Eastern domes (e.g., Canigou, Aston, Hospitalet) mostly expose Ordovician orthogneiss sheets that usually form their envelope, whilst western domes (e.g., Bossost, Lys-Caillaouas, Chiroulet, Lesponne) are devoid of orthogneisses (Figs. 2-4). The roof of the infrastructure corresponds to the upper contact of the orthogneisses with schistose rocks of the superstructure for the eastern domes. That roof lies within and preferentially near the top of Ordovician series for the western domes (Fig. 4). The eastern domes exhibit steep and locally southerly overturned limbs that are attenuated by the regional reversedextral shear zones (Denèle et al., 2007; Vilà et al., 2007; Figs. 2 and 4). Western domes such as the Bossost dome are less amplified and not clearly asymmetrical (Fig. 4, cross-section 2). Si foliations are dominantly shallowly dipping and the scattering of their poles on a N-striking vertical plane (Fig. 5c) attests to the E-W trend of the domes hinges (Fig. 3).

An overwhelming part of the Li lineations $(90 \%)$ in the Axial Zone trend $\mathrm{N} 70$ to $\mathrm{N} 120^{\circ} \mathrm{E}$, i.e., at a very low angle to the schistosity trajectories of the superstructure (Figs. $3 \mathrm{~b}$ and $5 \mathrm{~d}$ ). Hereafter, they are therefore called longitudinal Li lineations. They are shallowly plunging and acquire moderate to steep plunges on domes' flanks. $\mathrm{N} 90$ to $\mathrm{N} 120^{\circ} \mathrm{E}$ trending $\mathrm{Li}$ lineations are dominant over most of the Axial Zone, whereas $\mathrm{N} 70$ to $\mathrm{N} 90^{\circ} \mathrm{E}$ trending $\mathrm{Li}$ lineations are confined to the Canigou and Roc de France Massifs (Figs. 2 and 3). At the scale of some metamorphic domes (e.g., Canigou, and southern Bossost dome), Li trajectories have sigmoidal map trajectories showing a transition from longitudinal (domeparallel) flow at the core of domes to oblique stretching on domes' envelops (Fig. 3).

Si fabrics are affected by discreet to pervasive $\mathrm{C}^{\prime}$ shear zones and shear bands separating asymmetrical boudins and sigma-type porphyroclasts. Those shears bear lineations trending parallel to $\mathrm{Li}$ in the host rock and are commonly filled with fabric-free granitic material collected from the host migmatitic gneisses, attesting to the HT, melt-present conditions of non-coaxial longitudinal shearing of the infrastructure (e.g., Fig. 7a). A large number of Li stations $(50 \%)$ reveal top-to-the E or SE sense of shear, whereas top-tothe $\mathrm{W}$ or NW kinematics are documented at $31 \%$ of the $\mathrm{Li}$ localities (Figs. 3 and 7b). Stations with coexisting shear criteria of opposite sense and/or symmetrical boudins (Fig. 7c) represent $19 \%$ of the data (Fig. 3). The Aston and Hospitalet domes display preferential eastward shearing and others like the Chiroulet and Canigou are dominated by westward shearing (Figs. 2, 3, 7a and b). Longitudinal shearing also occurs in shear zones flanking the lateral termination of some domes (e.g., Hospitalet, Canigou, Figs. 2 and 3). At these locations, asymmetrical shear bands and shear zones evolve from melt-present, amphibolite-facies fabrics to greenschist-facies fabrics and strain localization, indicating syn-cooling shearing.

Li mineral-stretching lineations trending at a high angle to the structural grain (called hereafter transverse Li lineations) represent $10 \%$ of the measurements and are restrained to domes' envelop (Canigou, Aston and Chiroulet massifs; Figs. 2 and 3). Transverse lineations are associated with hundreds of meter to kilometer-thick retrograde, syn-melt (Fig. 7d) to 
greenschist-facies shear zones flanking the domes. Those shear zones have systematic normal-sense of shear.

In most domes, there is a gradient from longitudinal to transverse lineations, going from domes' cores to domes flanks, whereas in parts of specific domes (e.g., Aston, Canigou, Figs. 2 and 3) longitudinal and transverse Li lineations coexist. Given that both lineations are marked by HT minerals or mineral aggregates of leucosomes, they must have overlapped in time under HT and partial melting conditions. Be they associated with longitudinal, oblique or transversal stretching, the dome-flanking shear zones display systematic normal component of shearing and are retrograde, with shearing features going from melt-present or amphibolite facies metamorphic assemblages to brittle-ductile. This, together with the pattern of attenuated isograds around domes (e.g., Gibson and Bickle, 1994; Mezger and Régnier, 2016) indicates that extension contributed to dome exhumation. The study of the Bossost and Lys-Caillaouas domes (see Sect. 4.2 and 4.3 below) allows illustrating in greater details extensional dome emplacement modes as well as the strain interference patterns between domes' fabrics and those of the superstructure.

Metamorphic, strain and kinematic patterns preserved north of the North Pyrenean Fault (i.e., North Pyrenean and Ursuya massifs; Figs. 2 and 3) are distinct from those of the Axial Zone. Their fabrics may not be readily compared to those of the Axial Zone given the rotation the Axial Zone must have undergone in the Mesozoic with respect to areas located today north of the North Pyrenean Fault. However, for a purpose of convenience in the description of the structural pattern, the Axial Zone terminology is used here to refer to North Pyrenean fabrics. All the North Pyrenean massifs preserve granulitefacies rocks in their infrastructure. N-S stretching and shearing is pervasive in the Agly, St Barthélémy and Castillon massifs (Figs. 2 and 3). Shearing in the Agly and St Barthélémy massifs has been shown to result from extensional exhumation of the infrastructure and strain localization in detachments at its top (Bouhallier et al., 1991; de Saint-Blanquat, 1993). Interestingly, the Ursuya massif bears longitudinal $\mathrm{Li}$ in its infrastructure, whereas extensional shearing and detachment faulting was activated by top-to-the South (i.e., transverse) kinematics (our own observations; Figs. 2 and 3). This shows a kinematic contrast between deep stretching and higher-level shearing, comparable to the Canigou and Aston domes (Figs. 2 and 3 ).

\subsection{The Bossost dome}

In contrast with other domes of the Axial Zone, the Bossost dome shows relationships with the surrounding rocks of the superstructure that have not been obscured by the regional reverse-dextral shear zones. The dome has only been affected by localized post-Paleozoic faulting that has cut the dome in two sub-domes (Figs. 3, 4 and 8). The andalusite isograd roughly coincides with the outer concentric trajectories of the shallowly to moderately dipping foliations of the infrastructure (Si) and the steeper schistosity of the superstructure (Ss), with the noticeable exception of the southern flank of the southern subdome where the isograd rises up into the steep fabrics and folds of the Devonian sedimentary pile (Fig. 8a). The northern sub-dome exposes a deep portion of the northern flank of the original dome, whereas the southern sub-dome exposes mostly the E-W elongate core and the southern flank of the original dome. Peraluminous granite sills are intercalated in the dome, particularly in its northern flank, which display mineralstretching lineations (Li) of two main trends (see also Mezger and Passchier, 2003). The dominant lineation is longitudinal, trending parallel or at a low angle to the map axis of the dome and a few transverse lineations are documented in the vicinity of the northern margin of the dome, sometime on the same outcrops than the longitudinal $\mathrm{Li}$ (see also Mezger and Passchier, 2003). The fact that both longitudinal and transverse lineations are underlined by the same HT minerals suggests flattening strain in this part of the dome. The southern subdome exhibits overall sigmoidal $\mathrm{Li}$ trajectories going from longitudinal and $\mathrm{N} 100^{\circ} \mathrm{E}$ trending in its core to transverse (up to $\mathrm{N} 160-170^{\circ} \mathrm{E}$ trending) on its flanks (Fig. 8b). Top-to-the NW kinematics is documented from the northern limb and pervasive top-to-the SE or SSE shearing affects the southern flank. In both cases, shear criteria are towards the azimuth of plunge of Li lineations.

Top-to-the SE shearing is best expressed in a ca. $2 \mathrm{~km}$-thick shear zone (Fig. 9) exposed between Arres and Benos, which affects both the paragneisses and the overlying Devonian schists and marbles (Figs. 8a and 9; Mezger and Passchier, 2003). Shearing features are numerous, going from asymmetrical porphyroclast systems to extensional $\mathrm{C}^{\prime}$ shear zones and shear bands having contributed to thinning of the shear zone (Fig. 7e). Furthermore, shear zones and shear bands go from sillimanite-stable to brittle-ductile, indicating cooling of the rock pile during non-coaxial shearing and vertical thinning compatible with extension along the dome's flank. The extensional shear zone is crosscut by a steep mylonite zone localized in the Silurian black shales (Fig. 9). That mylonite zone fans up upward and northward to mold the domal envelop of the paragneisses and form an array of meter- to decameterscale, asymmetrical and anastomosed shears (Fig. 10a) with south-side up or top-to-the north kinematics, whereas northside up shears are also documented near the OrdovicianSilurian contact (see also García-Sansegundo, 1990, 1992, Fig. 10b). A detailed cross-section of this sector of the dome's flank is provided in Figure 10. Above, Devonian series are affected mostly by steep south-dipping thrusts rooted in the Silurian shales as well as steep folds with an axial planar schistosity corresponding to $\mathrm{Ss}$, i.e., the regional planar fabric of the superstructure (Fig. 9). Ls lineation in the superstructure is systematically down-dip on Ss. Near the Andalusite isograd, micaschists with shallow Si foliation are affected by micro to meter-scale, E-W trending upright folds with an axial planar cleavage. Over a few hundreds of meters going up in the structural pile, such folds become tighter up to transposition of Si by the steep Ss schistosity. Along this strain gradient, folded boudins are common, further attesting to the reworking of the dome-flanking shear zone by the steep fabrics of the superstructure (Ss and Ls).

The structural and kinematic configuration of the southern flank of the dome as reported above is symmetrical with respect to that of its northern limb. There, the shallowly Ndipping Si foliations of the dome are blanketed by the Silurian shales onto which north-dipping thrust faults branch. These faults affect, and are kinematically coherent with, the E-W upright folds and associated Ss schistosity of the overlying Devonian series (Fig. 9). The crestal region of the dome 


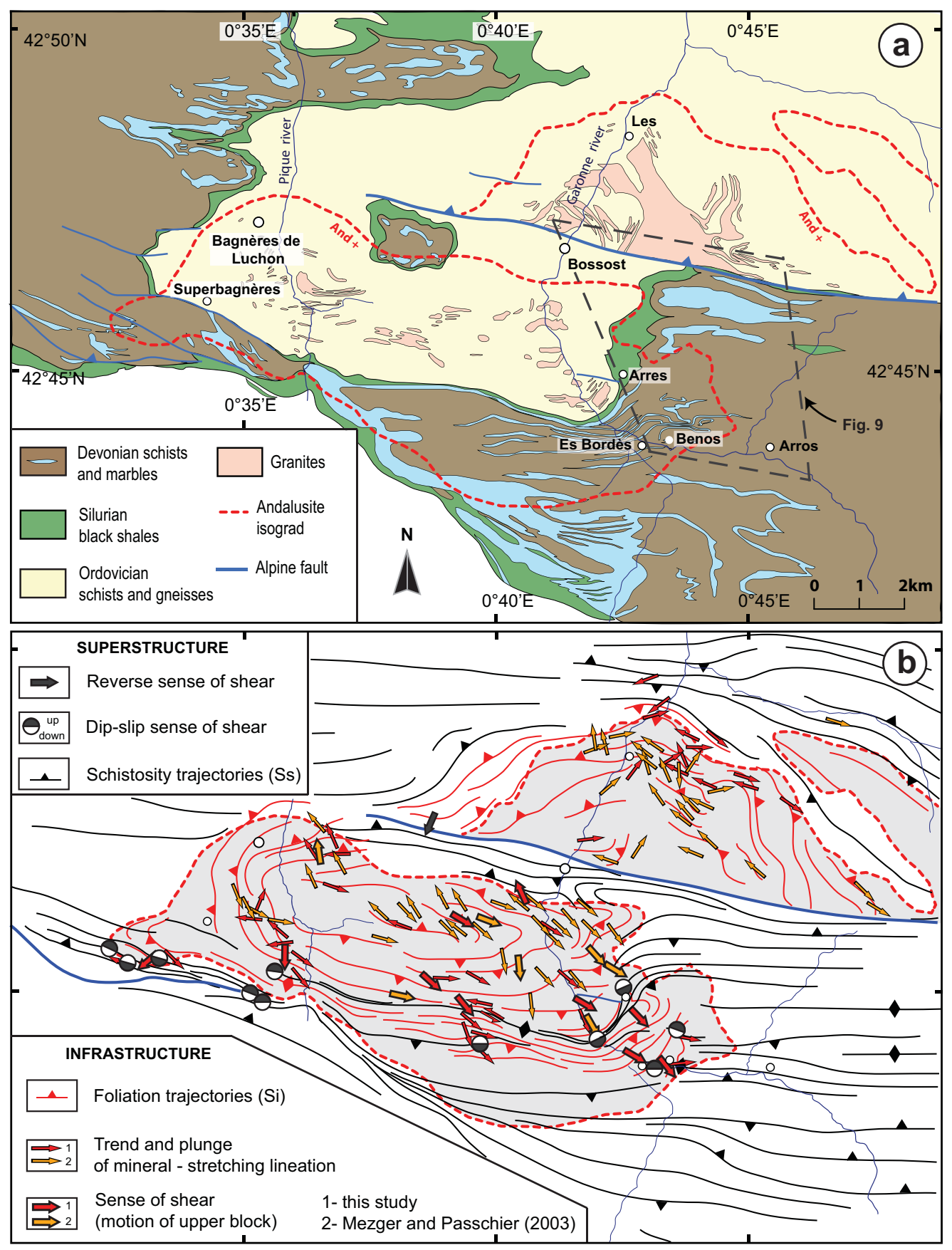

Fig. 8. (a) Geology of the Bossost dome and its adjoining rocks (modified from Kleinsmiede, 1960 and Clin et al., 1986). (b) Fabric patterns and kinematics of the area shown in (a), after Mezger and Passchier (2003) and the present work. Localities in (a) are also shown in (b).

displays fabric interference patterns formed by vertical shortening and longitudinal stretching $(\mathrm{Si} / \mathrm{Li})$, on one hand, and N-S shortening and vertical stretching $(\mathrm{Ss} / \mathrm{Ls})$, on another hand (Fig. 9). Such interference patterns are interpreted to reflect a longitudinal schistosity triple point along the dome's crest.

Exhumation of the infrastructure into the Bossost dome evolved from deep dominant longitudinal flow (as preserved in dome's core) to oblique, dominantly SE-directed, syn-cooling stretching and strain localization along extensional shear zones flanking the dome. Low-grade rocks of the superstructure preserved above the extensional contact of the dome exhibit penetrative fabric and fold patterns produced by N-S shortening, vertical stretching and reverse faulting on dome's flank towards the dome's crest. Shortening and thrusting recorded by the superstructure outlasted extensional exhumation of the dome, whereas no penetrative steep fabrics are preserved in the exposed infrastructure. This, together with the interference patterns developed between the dome's roof and the superstructure, suggests that dome amplification and regional shortening have overlapped in time. Field relations between the infrastructure and the superstructure as reported 


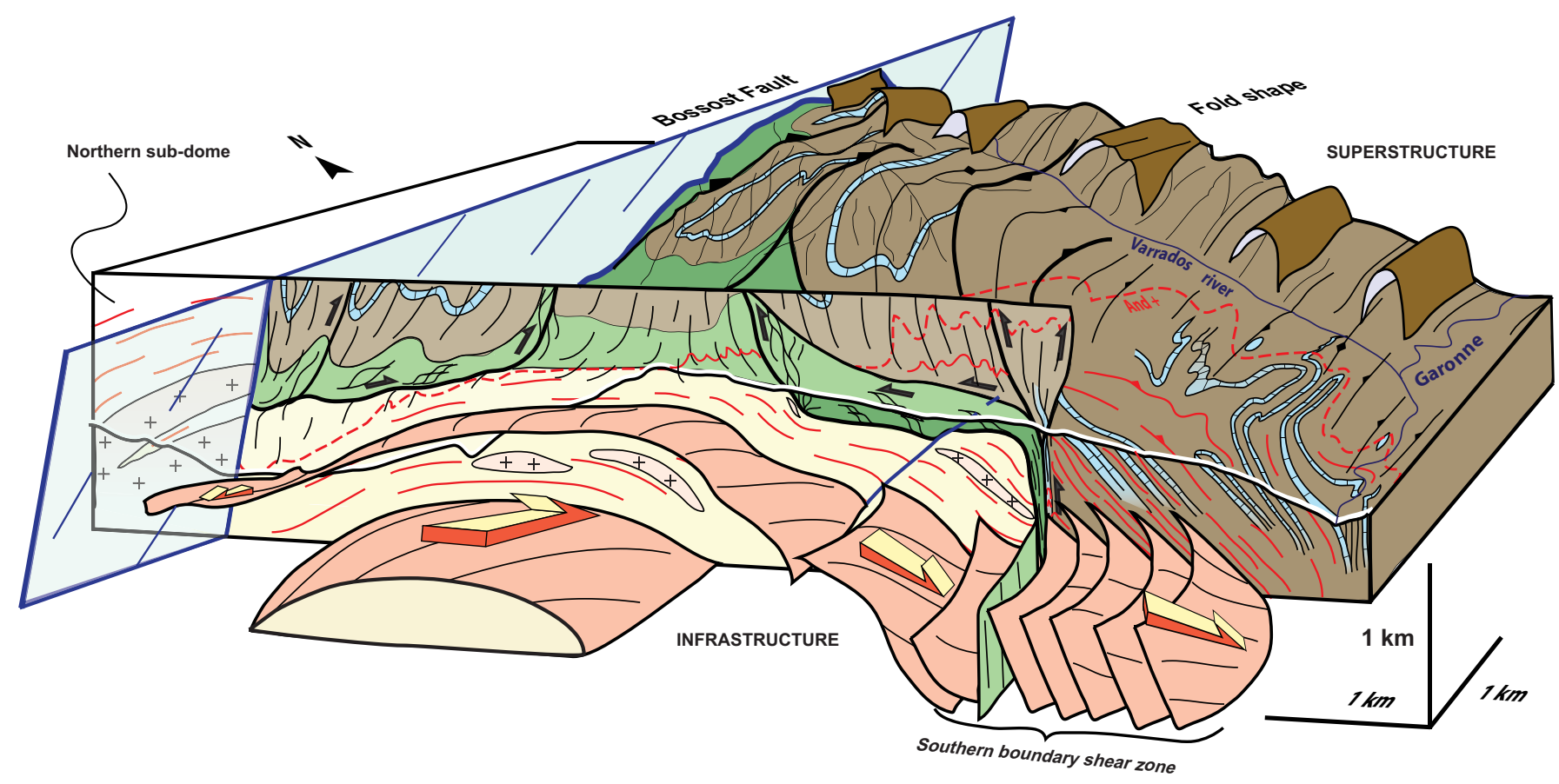

Fig. 9. Block diagram of the southeastern Bossost dome and its envelope (see Fig. 8 for location and color codes). See text for further explanation.

here for the Bossost dome are comparable to those we have examined around other domes in areas where the relationships with the superstructure have not been modified by the regional reverse-dextral shear zones (Chiroulet, Albères and Canigou domes; Figs. 2 and 3, see also Fig. 7f). Those observations argue for a common structural and kinematic framework of lower crustal flow, extensional exhumation and shortening patterns at the scale of the Axial Zone.

\subsection{The Lys-Caillaouas dome}

The Lys-Caillaouas massif exposes the southern limb of a N130 ${ }^{\circ}$-trending dome (Figs. 2-4, cross-section 2 ). The dome is made of paragneisses (locally migmatitic) hosting the LysCaillaouas pluton, which consists of a dioritic core surrounded by granites (Clin et al., 1986; Hilario-Orús, 2004) that ultimately crystallized at $300 \pm 2 \mathrm{Ma}$ (zircon SIMS U-Pb date of Esteban et al., 2015). The pluton is a sill interleaved within the paragneisses that roots into the Esera-Gistain shear zone, which truncates and bounds the dome to the South (Fig. 11a). Shallowly plunging mineral-stretching lineations (Li) in both the paragneisses and the plutonic rocks are dominantly WNW trending in the infrastructure (Fig. 3).

Bulk coaxial longitudinal deformation attested by opposite shear criteria and symmetrical boudinage affects the pluton's country rocks (Fig. 7c), whereas ESE-directed shearing characterizes the rest of the infrastructure (Figs. 3 and 11a). A southward strain gradient into the southern boundary shear zone is illustrated by fabrics evolving from sub-magmatic to mylonitic, indicating syn-cooling strain localization. Initially isotropic diorite is affected by typical C/ $\mathrm{S}$ fabrics (Gapais, 1989), whereas micaschists and paragneisses of the host rocks and the pluton's septa display systematic meter-scale $C^{\prime}$ shear zones and shear bands of sinistral-normal kinematics (top-to-the ESE) on progressively steeper foliations going southward (Fig. $11 \mathrm{~b}$ and c). Furthermore, the southern boundary shear zone marks a metamorphic break between the Sillimanite paragneisses in its footwall and very low-grade sediments in its hangingwall. The asymmetrical map shape and truncation pattern of the pluton by the shear zone and the asymmetrical fabric trajectories against the shear zone further argue for apparent sinistral sense of movement of the shear zone. The EseraGistain shear zone is therefore interpreted as a left-lateral transtensional shear zone that contributed to exhumation of the dome under ESE-directed extension (Figs. 3a and 11). Given the $307 \pm 3$ Ma SIMS U-Pb age of metamorphic zircons of the plutonic complex (Esteban et al., 2015) and the final crystallization age of the pluton $(300 \pm 2 \mathrm{Ma})$, longitudinal stretching and transtensional exhumation must have been active since ca. $310 \mathrm{Ma}$ and continued until after $300 \mathrm{Ma}$, considering that shearing occurred in the transtensional shear zones until after cooling from high temperature.

\subsection{Early Variscan deformation}

Pre-Ss map-scale folds, cleavage (S1) and faults are best observed near the Western termination of the Axial Zone (Mirouse, 1962; Valero, 1974; Müller and Roger, 1977; Matte, 2002) (Fig. 3). In this area, shallower levels of the superstructure are exposed given the differential longitudinal exhumation of the Axial Zone, which allowed a westward-increasing preservation of post-Ordovician stratigraphic pile westward (Fig. 4). Ss/Ls fabrics are less intense than in the rest of the Axial Zone and allow preservation of D1 features, whose kinematic significance is 


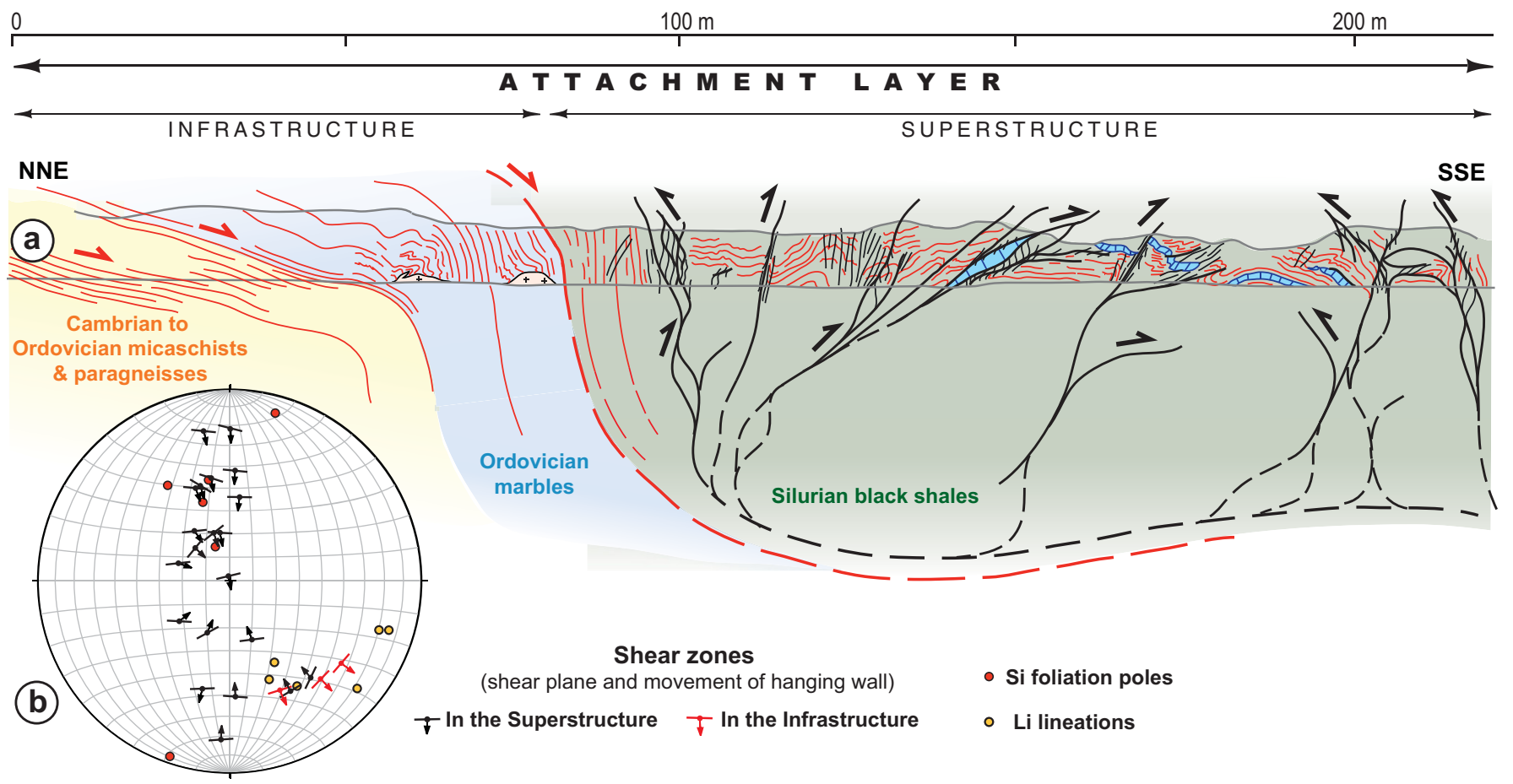

Fig. 10. (a) Detailed cross-section of the transition between the infrastructure and the superstructure interpreted as an attachment (southeastern limb of the Bossost dome, road cut NW of Arres, Fig. 8a). (b) Structural elements measured along the cross-section (lower hemisphere, equal area projection). Schistosity and associated shears of the superstructure (in black) are superimposed on the foliations molding the roof of the infrastructure (in red). The steep reverse shears are both North-and South-verging and branch onto the roof of the infrastructure. By contrast, the regional transpressive shear zones cut across the attachment (Fig. 4).

unambiguously interpreted, as opposed to locations further to the East (Guitard et al., 1984, 1998). Over the area south of the Eaux-Chaudes pluton (Fig. 2), Matte (2002) reported southwestward to westward thrusting on the basis of overturned to recumbent fold asymmetries and $\mathrm{F} 1$ folds-S1 cleavage relationships. We report here on a cross-section made at the western tip of the Axial Zone (Figs. 3 and 12). Devonian carbonates and overlying late Carboniferous flysch series are involved in $\mathrm{km}$-scale folds inclined to slightly overturned towards the west (Fig. 12a). Folds short limbs are affected and attenuated by E-dipping thrust faults. In the field, such faults typically show down-dip striations as well as top-to-the West reverse shear senses, consistent with microfolds' asymmetry (Fig. 12b). Such a structural pattern, which was also described by García-Sansegundo (1992, p. 251), is observed in the Ordovician-Devonian series of the Basque Massifs as well despite the occurrence of a younger E-W Ss cleavage (Figs. 2 and 3) (Valle de Lersundi et al., 1972; Villalobos Vilches and del Valle de Lersundi, 1973 and our own observations). Such geometries and kinematics indicate that the structural style of early Variscan (D1) deformation was that of a west-vergent fold-and-thrust belt in the westernmost Axial Zone and the Basque Massifs. Whether D1 fold-and-thrust relicts found elsewhere in the Axial Zone (Fig. 3) were originally N-S and rotated to roughly E-W by the main deformation that produced Ss is not known. D1 folds and thrusts may as well have originally been part of a virgation going from ESE-trending in most of the Axial Zone to N-trending in the westernmost Axial Zone and Basque Massifs.

\subsection{Late- and Post-Variscan deformation}

In the Basque Massifs, a N-striking fracture cleavage is superimposed on Ss over an area coinciding with a regional gravity anomaly surrounding the $267 \mathrm{Ma}$ Aya pluton (Figs. 2 and 3 ; see Debon and Guitard, 1996). This cleavage being crosscut by the Alpine cleavage affecting the neighboring Triassic deposits (Villalobos Vilches and del Valle de Lersundi, 1973; our own observations), it is most likely Permian in age and linked to the emplacement of the Aya pluton (Denèle et al., 2012).

In the Southern part of the Axial Zone, Alpine thrust faults root into the steep Variscan shear zones and acquire shallower northern dip towards the surface. These faults achieved thrusting of basement over the Meso-Cenozoic series of the Southern Pyrenean zone, with cumulated throw ranging from a few kilometers to $10-15 \mathrm{~km}$ (e.g., the Eaux-Chaudes and Orri thrusts; Fig. 4, cross-sections 2 and 3, see also Déramond, 1979; Majesté-Menjoulas, 1979).

\section{Structural synthesis}

The consistent orientation of Ss/Ls fabrics of the Axial Zone define a homogeneous strain field reflecting N-S horizontal shortening and dominantly steep stretching (i.e., bulk vertical pure shear) with a subsidiary component of simple shear (as attested by dominant north-side-up kinematics in the southern Axial Zone). The map symmetry of the regional anastomozed shear zone pattern with respect to 

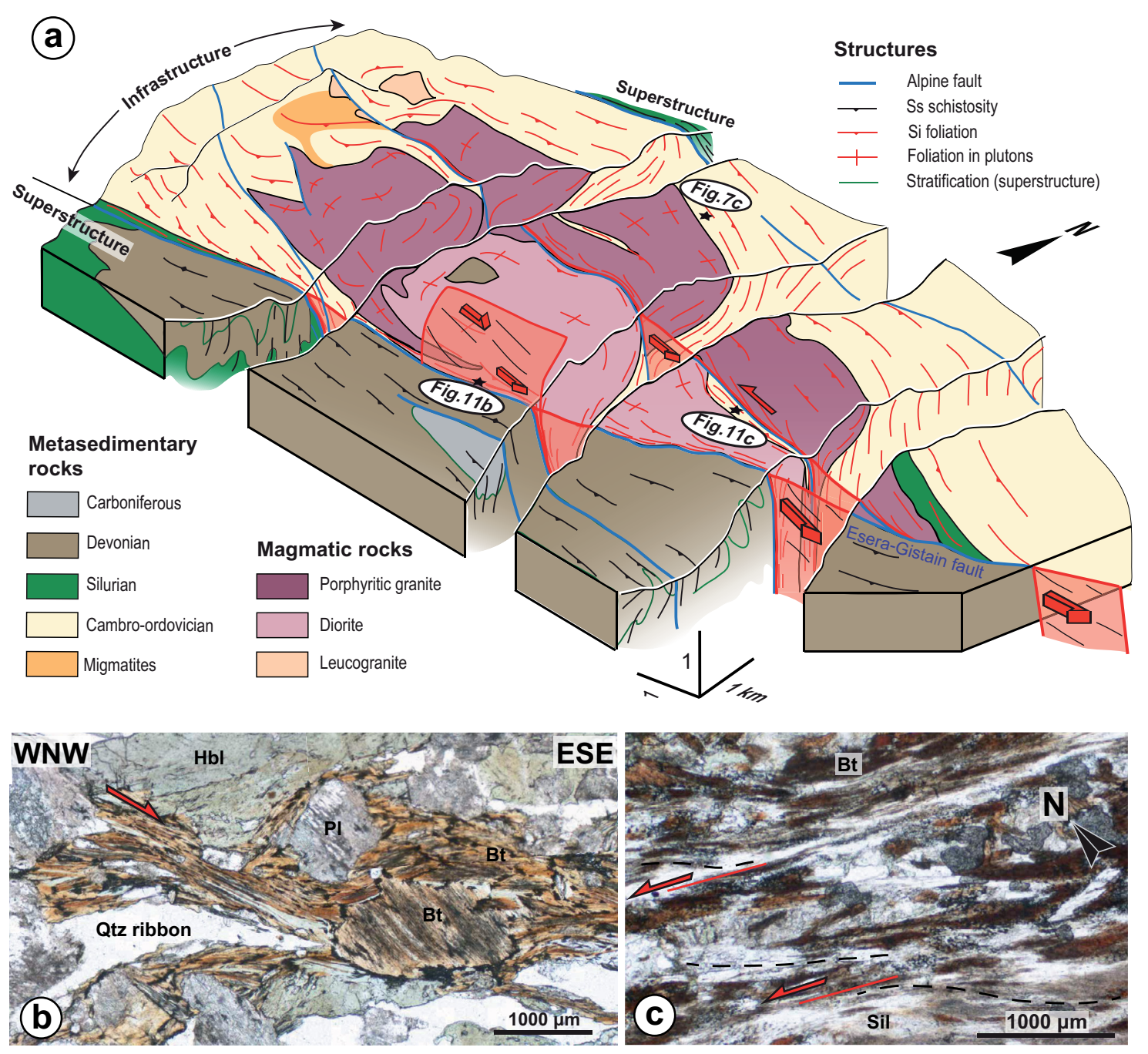

Fig. 11. (a) Schematic 3D model of the Lys-Caillaouas massif. Compiled from maps and cross-sections of Clin et al. (1986, 1989), Kriegsman et al. (1989), Hilario-Orús (2004) and the present work (see Figure 3a for kinematic information in map view). Alpine cleavage along the EseraGistain fault, which reactivates the shear zone, is omitted. (b) Normal-dextral C/S structures observed in the diorite along the southern boundary shear zone, indicating top-to-the ESE shear sense (the foliation dips ca. $40^{\circ}$ to the South). (c) Plane view of $\mathrm{C}^{\prime}$ shear bands in sillimanite micaschists against the deformed plutonic rocks (sinistral sense of shear). Thin-sections are cut in XZ planes of the deformation ellipsoid. Mineral abbreviations from Kretz (1983).

rectilinear trajectories of steep Ss is remarkable, with the schistosity bisecting the angle between the two sets of shear zones (Fig. 3b). Such a symmetry is indicative of a kinematic coherency between, and coeval activation of, the regional schistosity and the shear zones in response to bulk inhomogeneous deformation (Gapais et al., 1987, 2005). This deformation was partitioned between bulk pure sheardominated deformation in low strain lenses and non-coaxial strain localization in the reverse-dextral (i.e., transpressive) shear zones. The regional pattern of bulk inhomogeneous dextral transpression (Fig. 3b) is also consistent with structural patterns documented at various scales throughout the Axial Zone and particularly those produced by synkinematic pluton emplacements (Carreras and Capella, 1994; Gleizes et al., 1997, 1998b; Denèle et al., 2007, 2009; Carreras and Druguet, 2014).

Pervasive longitudinal stretching and shearing of the infrastructure attest to lateral flow on a regional scale. Lateral flow of the infrastructure is kinematically compatible with transverse shortening of the superstructure. Furthermore, longitudinal flow of the infrastructure and shortening deformation in the superstructure overlapped in time for at least ca. $15 \mathrm{Myr}$. Indeed, syn-kinematic HT metamorphism, partial melting and sill emplacement in the infrastructure lasted from at least $\sim 310$ to $294 \mathrm{Ma}$ (possibly up to ca. $320 \mathrm{Ma}$; e.g., Aguilar et al., 2014), whereas bulk inhomogeneous transpression and syn-kinematic pluton emplacements in the superstructure lasted from $\sim 310$ to $290 \mathrm{Ma}$. This geochronological overlap is also documented at the scale of specific domes/plutons such as the Lys-Caillaouas dome (Esteban et al., 2015), La Jonquera pluton (Aguilar et al., 2015) and the Aston dome (Denèle et al., 2009, 2014; Fig. 2).

The emplacement mode of the gneiss domes of the Axial Zone attests to the extensional exhumation of the ductile buoyant infrastructure in the lower superstructure. Although they ultimately evolved under retrograde metamorphic 

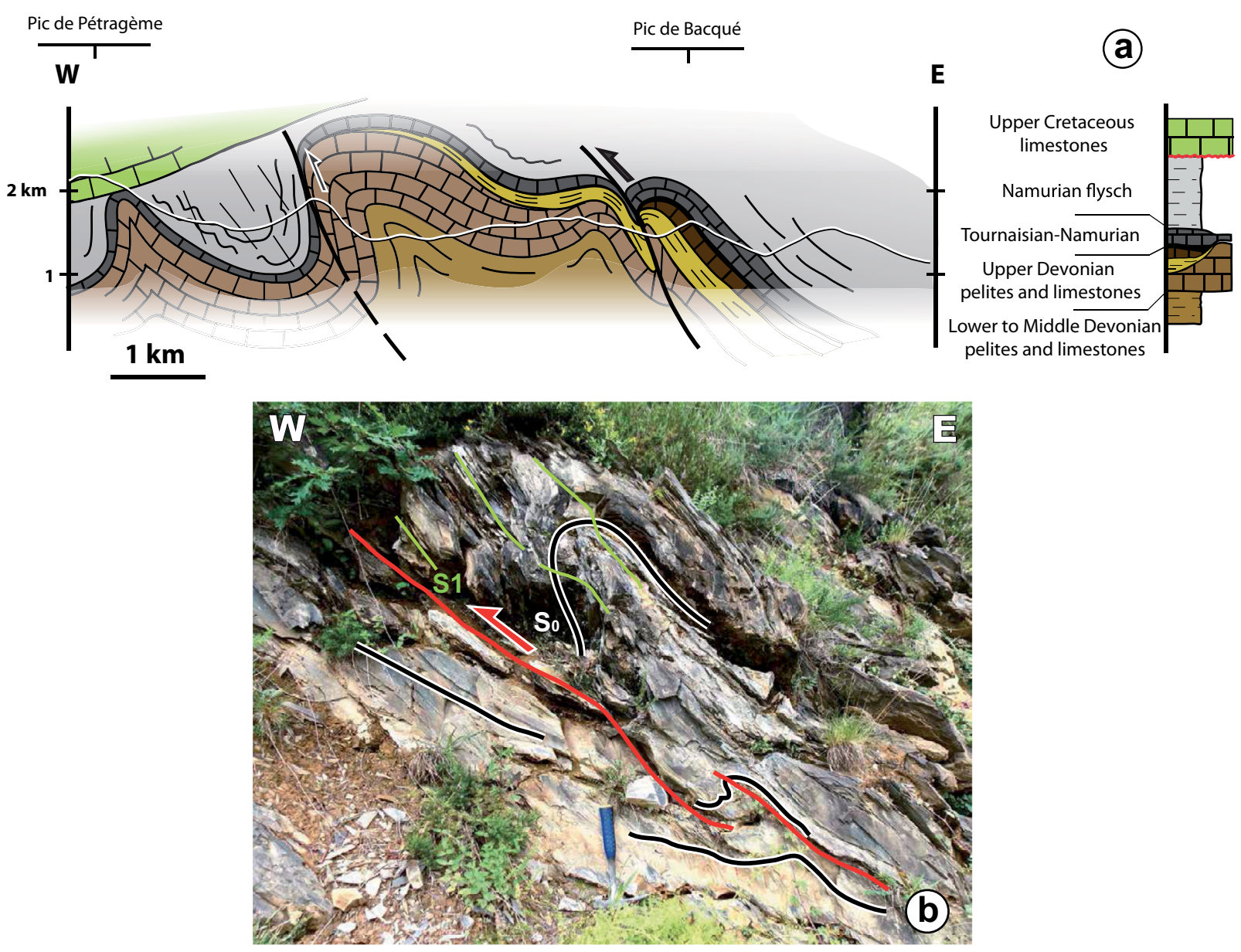

Fig. 12. (a) Cross-section at the Western termination of the Axial Zone, preserving early Variscan (D1) structures. See Figure 2 for location of the cross-section. (b) Southwestward verging folds with axial planar cleavage and top-to-the W reverse shears, Namurian flysch (outcrop located a few kilometers north of the cross-section).

conditions, extensional fabrics along domes' flanks are kinematically compatible and overlap in time with syn-melt/ high-grade lateral flow fabrics of the deeper infrastructure. The upper pile of those extensional fabrics is overprinted by the steep shortening fabrics of the superstructure that yet do not penetrate the deeper infrastructure. This shows that the shallow fabrics of the infrastructure must have been functional during part of the regional shortening. Given the structural chronology, kinematic relationships and time overlap between the deformation patterns of the infrastructure and the superstructure, we interpret lateral flow of the infrastructure to have been constrained, under convergence, by transverse shortening that is recorded by transpression of the superstructure. Likewise, extensional doming of the infrastructure must have taken place during shortening.

The Li lineation and shear map patterns for the Bossost and Lys-Caillaouas cases indicate a sinistral transtensional component of stretching during extensional emplacement of the domes. Conversely, those of the Canigou and Bouillouses domes suggest dextral transtension, whereas those of the Albères, Roc de France, Hospitalet and Lesponne domes would indicate dominant longitudinal extension (Figs. 2 and 3). Finally, some domes such as the Aston and the Chiroulet show both longitudinal and transversal extensional shearing. Still, transverse extensional shearing along dome flanks is largely subsidiary and $60 \%$ of all the shear criteria collected in the infrastructure range from top-to-the ESE to top-to-the S. This indicates that a dominant transtensional (i.e., oblique) component of stretching was permitted under convergence to allow exhumation of the infrastructure. This transtensional component of stretching is also indicated by the obliquity of longitudinal Li lineations on the domes' hinges (comparison of Fig. 5c and d). The dominance of southeastward-directed extension requires a favorable boundary condition to the east or southeast of the Pyrenees (in present-day coordinates).

Potential (early) thickening history of the infrastructure has been erased by lateral flow and extension at its roof. Although interference strain patterns may argue for local multistage deformation histories, superimposition of distinct and diachronic regional Variscan deformation phases cannot be substantiated at the scale of the Pyrenees from 310 Ma onward (i.e., after D1 fold-and-thrust deformation; see also Carreras and Capella, 1995 in their reply to Aerden, 1995). Our conclusions concur with those of Mezger and Passchier (2003), who argued in their study of the Bossost dome for local extension permitted under regional shortening regime. Our 

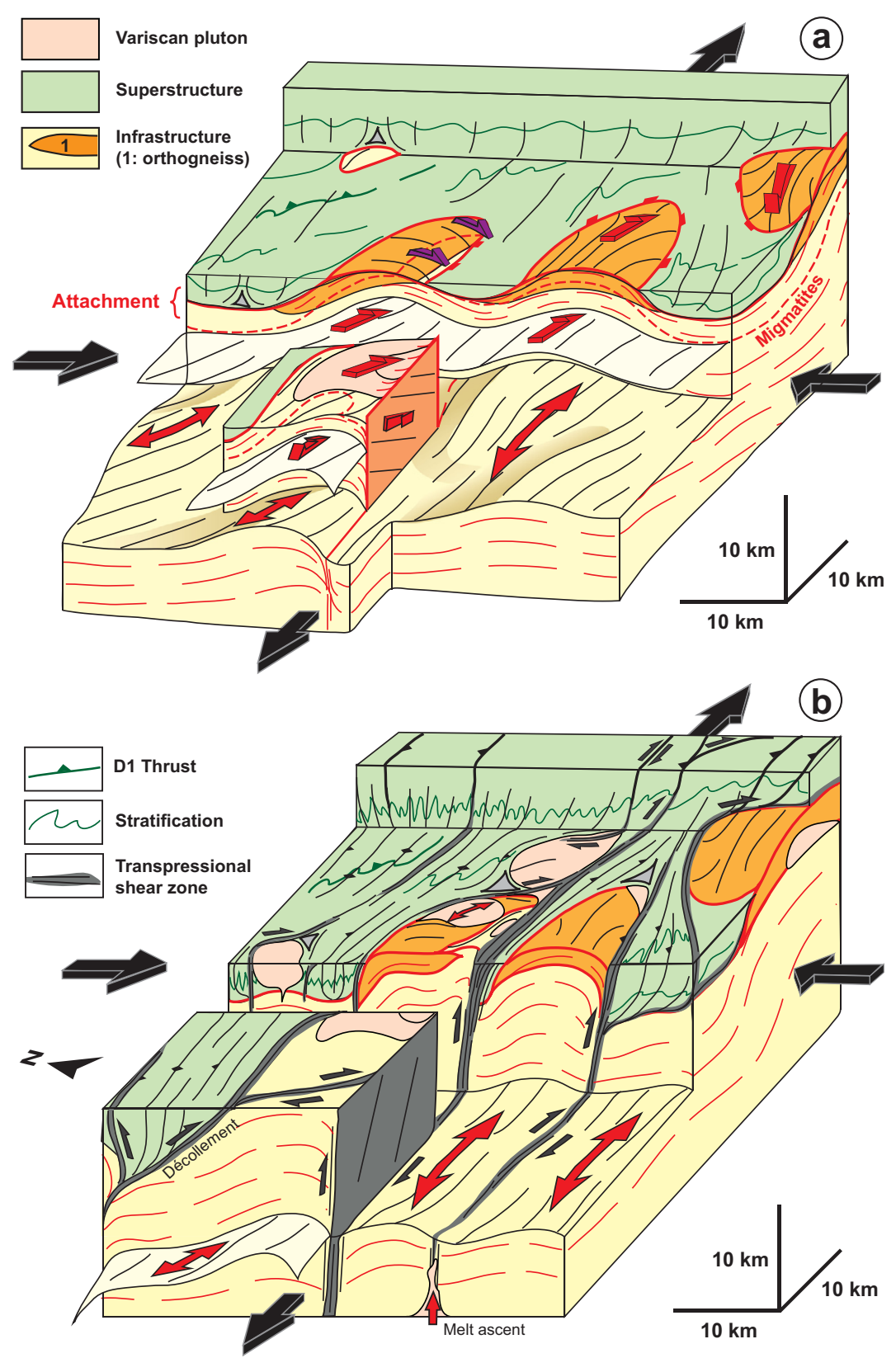

Fig. 13. Block-diagram summarizing two stages in the late-Variscan crustal evolution of the Axial Zone of the Pyrenees. See text for further explanations.

work further allows addressing the causes and consequences of coeval orogen-parallel lower crustal flow, extensional doming and orogen-normal shortening at the scale of the Variscan Pyrenees.

\section{Discussion}

\subsection{Three-dimensional flow mode of the Variscan Pyrenean crust}

Coeval transpression of the superstructure and lateral flow of the infrastructure typically compare to those of ultra-hot orogens, indicative of a particularly weak lithosphere submitted to convergence (Cagnard et al., 2006; Cruden et al., 2006; Chardon et al., 2009). The transition zone between the infrastructure and the superstructure as originally defined by de Sitter and Zwart (1960) represents an attachment (Chardon et al., 2009; Figs. 10 and 13a). The role of the attachment was to maintain vertical strain continuity through the crust by monitoring the conversion of orogen-normal shortening into vertical stretching and lateral flow between the superstructure and the infrastructure, respectively. The attachment further had to allow the rise of the partially molten buoyant infrastructure into transtensional domes (Fig. 13a). The reason why transtension, instead of orogen-parallel extension, enhanced dome emplacement is that it combines eastward lateral escape (orogen-parallel flow end-member) and gravitational collapse (orogen-normal end-member) 
(Chardon et al., 2011). The attachment also had to absorb differential horizontal and vertical displacements due to the contrasted deformation modes of the lower and upper crusts that imply spatially and temporally contrasted transversal contraction and lateral elongation. We interpret transtensional dome emplacement and slip on the regional transpressive shear zones to have absorbed kinematic incoherencies due to those contrasts. Although the attachment's thickness and kinematics evolved through space and time, its roof seems to roughly mark an isotherm (i.e., the andalusite isograd), which must have dictated a rheological threshold in the crust.

Transtensional doming into a thickening superstructure led to limited finite exhumation so that infrastructure rocks were not brought to the surface and the domes are not flanked by extensional sedimentary basins. Therefore, they are not metamorphic core complexes as defined in the Basin and Range province (e.g., Davis and Coney, 1979; Lister and Davis, 1989). We suggest that they represent syn-convergence transtensional gneiss domes, which may be common in thermally mature convergent orogens and have been mistaken for metamorphic core complexes or compressive or diapiric domes.

Shortening deformation of the superstructure outlasted fabrics of the exhumed roof of the infrastructure. Likewise, the regional transpressive shear zones reactivate, or are superimposed on, the extensional shear zones flanking the domes ( $e$. g., Canigou dome, Figs. 2 and 4). Furthermore, domes have been amplified by N-S shortening and locally overturned by reverse-dextral slip on the regional shear zones (Vilà et al., 2007; Denèle et al., 2007, 2009; Figs. 4 and 13b). The regional transpressive shear zones crosscut the attachment (Figs. 4 and 13b) and were active until after ca. $290 \mathrm{Ma}$, i.e., the age of the youngest pegmatites they affect (Druguet et al., 2014; Van Lichtervelde et al., 2017). At least some of them must have been through-going during earlier (310-300 Ma) crustal flow of the infrastructure because they acted as magma channels at the time (Denèle et al., 2008, Fig. 13b). Furthermore, synkinematic mineral assemblages in the shear zones attest to cooling during strain localization. These considerations argue for increasing coupling across the attachment during crustal cooling and stiffening of the infrastructure after ca. $295 \mathrm{Ma}$ (i.e., the latest cooling age from high temperature of the infrastructure).

\subsection{Implications for early Variscan and post-Variscan deformation of the Pyrenees}

Despite intense deformation of the superstructure where upright isoclinal folds are common, the envelope of the stratigraphic markers and the metamorphic isograds remained roughly horizontal (Fig. 4). This precludes the occurrence of Variscan crustal-scale thrusts that would have disrupted the stratigraphic pile and produced major metamorphic breaks. Therefore, D1 deformation must have involved thin-skinned instead of thick-skinned fold-and-thrust tectonics. Likewise, early (pre-main Ss cleavage) recumbent fold nappes involving the infrastructure are also unlikely in the Pyrenees.

Maintenance of a flat envelop for the Paleozoic sedimentary pile and the isograds over the Axial Zone also suggests that the occurrence of Alpine thrusts other than those reported on Figures 3 and 4 may be precluded (see also Carreras and Druguet, 2014). Such extra thrusts have been drawn across the Axial Zone to absorb Alpine shortening, implying staking, internal deformation and northward (up to $90^{\circ}$ ) tilting of basement duplexes (Muñoz, 1992; Beaumont et al., 2000). The present study suggests instead that the Axial Zone is an asymmetrical Alpine pop-up, whose southern half has been flexed as a consequence of slip along curved, north-dipping thrust(s), forming an upward-fanning pattern of Variscan schistosity (e.g., Fig. 4, cross-section 3). The Alpine convergence record in the Pyrenees therefore needs to be substantially revised.

\subsection{The Pyrenees within the closing Iberian- Armorican syntax}

If the map development of the Cantabrian orocline is now well constrained and dated, its causes remain elusive (Gutiérrez-Alonso et al., 2012). Martínez-Catalán (2011) suggested that Variscan oroclines resulted from orogenparallel shortening within the late Paleozoic dextral shear corridor linking the Appalachians to the Urals defined by Arthaud and Matte (1977). Carreras and Druguet (2014) proposed that the Iberian-Armorican arc was a back fold developed in between large-scale en-échelon Riedel faults (especially the North Pyrenean fault) within that same dextral corridor. Whatever the far-field conditions, as a limb portion of the Cantabrian orocline, the Pyrenees developed a strain pattern that fits into the orocline closure scheme in a way that is summarized as follows.

Thin-skinned fold-and-thrust deformation attained the Pyrenees around 320-310 Ma, i.e., at a time HP nappe stacking (380-360 Ma) and exhumation (360-350 Ma) had long occurred in the hinterland of the orogen (Faure, 1995; Faure et al., 2008, 2009; Matte, 2007; Martínez-Catalán et al., 2009; Ballèvre et al., 2009; 2014; Fig. 14a and b). The nappe stack became subject to partial melting and magmatism under a regime of dominant orogen-parallel flow that led to the emplacement of extensional gneiss domes and plutons (Fig. 14b). Later on (Fig. 14c), partial melting and lateral crustal flow came to affect a wider hinterland growing at the expense of its southern foreland that was recording active thrusting (e.g., Matte, 2007; Martínez-Catalán et al., 2009). Final amplification of the Iberian-Armorican syntax was recorded in its core by the closure of the Cantabrian orocline between 305 and $295 \mathrm{Ma}$ (Weil et al., 2010). Coeval shortening and lateral flow of the Pyrenees from 310 to $300 \mathrm{Ma}$ under an increasing component of transpression until at least $290 \mathrm{Ma}$ responded to orocline closure. The Pyrenean strain field recorded lateral (i.e., limb-parallel) eastward escape of the crustal material pinched out in the inner syntax and extruded outward, whereas transpression recorded shortening across the orocline's limb (Fig. 14c). In this context, the dextral component of transpression in the Pyrenees has been imposed by the obliquity between overall N-S convergence and the NW-SE strike of the northern limb of the orocline (in Permian coordinates, Fig. 14c). The Pyrenees are peculiar among the HT terrains of the Variscan belt of SW Europe in the sense that the last deformation that left an imprint on the crustal architecture is compressional instead of being related to extensional collapse. This peculiarity is explained by the position of the Pyrenees 


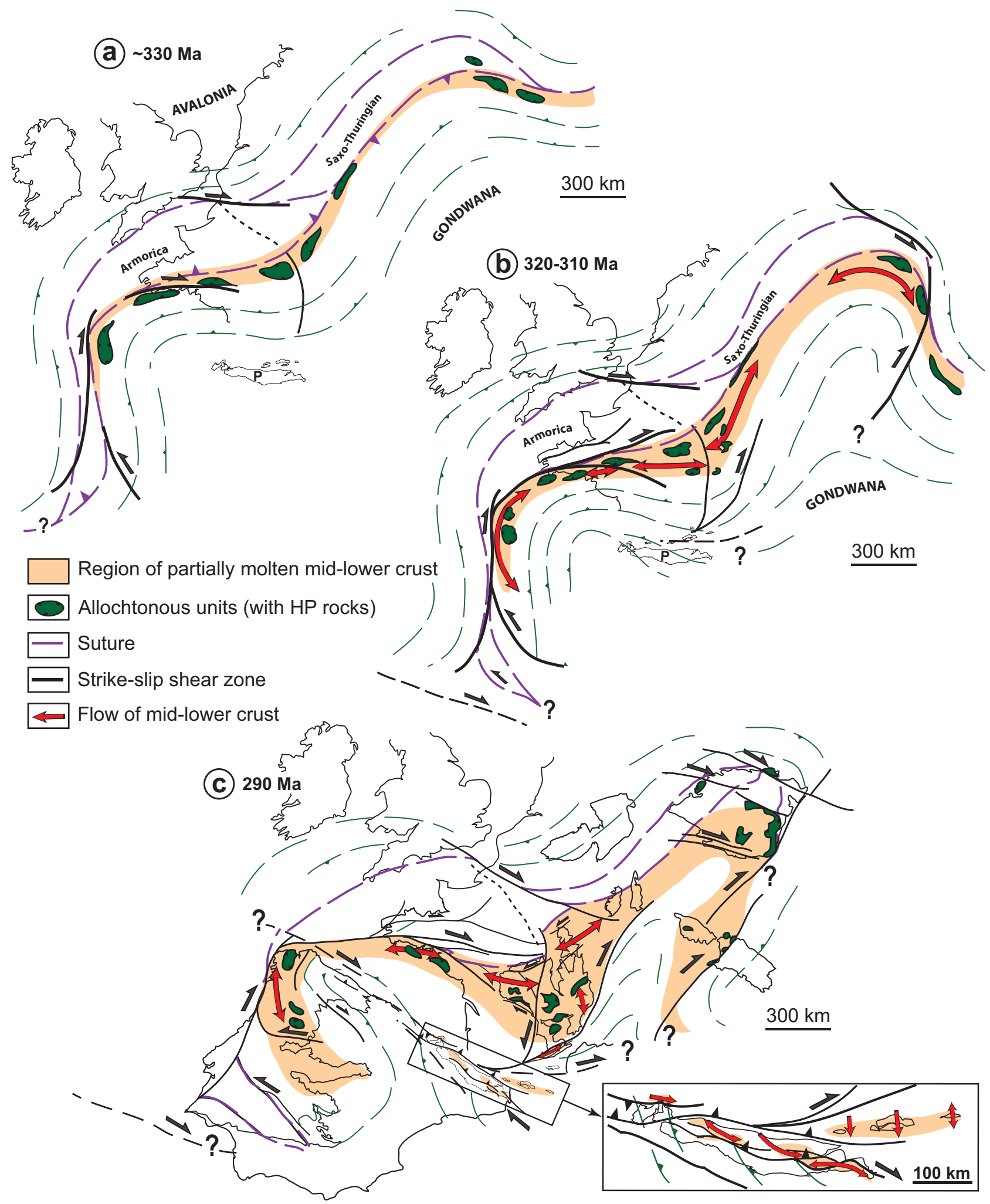

Fig. 14. Three-stage reconstruction of the Iberian-Armorican arc during the Carboniferous and the Permian. (a) Late collision stage at ca. $330 \mathrm{Ma}$. (b) Syn-convergence extension of the hinterland and fold-and-thrust tectonics in the southern foreland (ca. 320-310 Ma). (c) End of orocline bending, intra-syntax HT deformation (ca. 310-290 Ma). The inset shows how syn-convergence lateral flow pattern of the Pyrenees fits into the frame of the closing syntax. Note that N-S extensional shearing in the North Pyrenean massifs may be younger (see text for further explanation). The Axial Zone of the Pyrenees has been kept attached to Iberia, which is restored to its Permian position. Main sources for map and kinematic data outside the Pyrenees: Faure et al. (2009), Ballèvre et al. (2014), Franke (2014), Lardeaux et al. (2014). Palinspastic position of Iberia is adapted from Carreras and Druguet (2014) and those of Corsica and Sardinia from Edel et al. (2014). 
along the limb of the closing Cantabrian orocline. Orocline closure pinched off the crust enclosed in the inner syntax that escaped towards the SE (in Permian coordinates; Fig. 14c), providing a lower-strength, favorable boundary condition compared to the orocline's hinge.

$\mathrm{N}-\mathrm{S}$ extensional exhumation of the granulitic crust in the North Pyrenean massifs does not readily fit into the kinematic framework described above (Fig. 14c). However, some of these massifs display longitudinal mineral stretching lineations (Fig. 3) and recent zircon $\mathrm{U}-\mathrm{Pb}$ dating on the granulites suggests extension-driven cooling at high temperature significantly later than in the Axial Zone (300-280 Ma; Lemirre et al., 2016). Furthermore, the relative position of the North Pyrenean massifs and the Axial Zone on both sides of the North Pyrenean fault is not well constrained for pre-Cretaceous times. Therefore, although they possibly underwent early Axial Zone-like lateral flow, the North Pyrenean massifs preserve the record of N-S midto Late Permian extension comparable to that affecting pervasively the French Massif Central (Malavieille, 1993; Burg et al., 1994, Faure, 1995; Matte, 2007; Figs. 1 and 14c). Such a transverse extension may have been driven by collapse of a wide hinterland of higher topography, as opposed to transpression and lateral escape of the foreland Pyrenean crust from the closing orocline. Partitioning of stretching/extension directions between those two domains was allowed by the North Pyrenean fault.

The Pyrenean crust was an abnormally hot foreland undergoing regional HT/LP metamorphism between ca. 310 and $300 \mathrm{Ma}$. Syn-convergence HT-LP metamorphism cannot be the sole consequence of the thermal maturation of an overthickened crust (Thompson and England, 1984), especially considering the absence of crustal-scale thrust and the lack of HP metamorphic relicts in the case of the Pyrenees. For that, an additional asthenospheric heat source is required in a context of attenuated or missing lithospheric mantle (Sandiford and Powell, 1991; Chardon et al., 2009). The switch from crustal to mantle and hybrid sources of 310-290 Ma plutonism in the Pyrenees (e.g., Kilzi et al., 2016) is in agreement with such a lithospheric configuration that enhances mantle-crust interactions. This switch, which is also documented across both limbs of the syntax after ca. 330 Ma (Bussy et al., 2000; Gébelin et al., 2009; Gutiérrez-Alonso et al., 2011a, b; Couzinié et al., 2014), may be due to lithospheric mantle delamination (Rey et al., 1997; Gutiérrez-Alonso et al., 2011a, b; Laurent et al., 2017; see also the critical review of MartínezCatalán et al., 2014). Franke (2014) argued that magmatism and HT-LP metamorphism were widespread over the entire orogen and its forelands before $330 \mathrm{Ma}$ and suggested a "non orogenic" cause for a modification of the lithosphere such as mantle plumes. But pre-320 Ma zircon U-Pb and monazite U$\mathrm{Th}-\mathrm{Pb}$ ages from the vicinity of flysch basins are those of crustally-derived melts and have been challenged by recent geochronological reappraisals as exemplified in two key areas such as the Pyrenees (Denèle et al., 2014) and the Montagne Noire (Roger et al., 2015; Poujol et al., 2017; Fig. 1).

Whatever the cause(s) for the weakening of the lithospheric mantle under the Iberian-Armorican syntax (thermal erosion or delamination), a thin and hot lithosphere appears as a necessary condition for the 3D flow mode of the Pyrenean crust during orocline closure. A thin and hot lithosphere is also required for orocline bending because a stiff foreland lithosphere that may not have been bent otherwise.

\section{Conclusion}

The specificity of the Pyrenean Variscan crust is to have evolved from a cold foreland setting to a hot orogenic setting without having undergone typical mountain building processes in the meantime (crustal-scale thrust nappe tectonics, HP metamorphism). As a thin and hot portion of continental lithosphere, the Pyrenean domain has been involved in the closure of an orogenic syntax by developing strain and metamorphic patterns typical of hot orogens. These patterns reflect the competition between upper crustal thickening and lateral flow of a weak and buoyant lower crust within the kinematic framework of a closing syntax.

An attachment has acted as a structural buffer between laterally flowing lower crust and transpressional thickening of the upper crust of the Variscan Pyrenees. This attachment corresponds to a temperature-controlled rheological threshold, which also allowed for the formation of transtensional gneiss domes at the roof of the lower crust during convergence. Transtensional unroofing of the domes into the upper crust involved a combination of forced lateral flow and buoyancy of the partially molten lower crust. Late shortening-induced buckling of the domes during strain localization in steep crustal-scale transpressive shear zones attests to an increasing coupling between the lower crust and the upper crust during regional cooling. The combination of dextral transpression and eastward flow in the Pyrenees results from the shortening and lateral escape of hot and weak crust along the inner northern limb of the closing Cantabrian orocline between ca. 305 and $295 \mathrm{Ma}$. The conditions for the switch from crust- to mantlederived magmatism in the Iberian-Armorican arc, orocline closure and escape of hot foreland crust from the syntax are fulfilled in a context of thin and hot lithosphere having been delaminated or thermally eroded.

\section{Supplementary Material}

Supplementary File 1 is the structural map of Figure 3 in A3 format and full resolution. Supplementary File 2 countains the map of all field stations and the sources of the data compiled from published works.

The Supplementary Material is available at http://www.bsgf.fr/ 10.1051/bsgf/2017206/olm.

Acknowledgements. This work was supported by the BRGM through the Référentiel Géologique de la France program (RGF). The paper benefited from the constructive reviews of an earlier version by J.R. Martínez-Catalán and an anonymous referee. W. Franke and two referees made comments that helped improve the manuscript. The newly acquired and compiled structural data will be available on the RGF website (www.rgf.brgm.fr).

\section{References}

Abati J, Gerdes A, Suárez JF, Arenas R, Whitehouse MJ, Fernández RD. 2010. Magmatism and early-Variscan continental subduction in the northern Gondwana margin recorded in zircons from the basal units of Galicia, NW Spain. Geol Soc Am Bull 122: 219-235. DOI: $10.1130 / \mathrm{B} 26572.1$. 
Aerden DG. 1995. Tectonic levels in the Palaeozoic basement of the Pyrenees - a review and a new interpretation: discussion. J Struct Geol 17: 1489-1491. DOI: 10.1016/0191-8141(95)00049-J.

Aguilar C, Liesa M, Castiñeiras P, Navidad M. 2014. Late Variscan metamorphic and magmatic evolution in the eastern Pyrenees revealed by U-Pb age zircon dating. J Geol Soc 171: 181-192. DOI: 10.1144 /jgs2012-086.

Aguilar C, Liesa M, Štípská P, Schulmann K, Muñoz JA, Casas JM. 2015. P-T-t-d evolution of orogenic middle crust of the Roc de Frausa Massif (Eastern Pyrenees): a result of horizontal crustal flow and Carboniferous doming? J Metam Geol 33: 273-294. DOI: 10.1111/jmg. 12120.

Allen MB, Macdonald DIM, Xun Z, Vincent SJ, Brouet-Menzies C. 1998. Transtensional deformation in the evolution of the Bohai Basin, northern China. Geol Soc Spec Publ 135: 215-229. DOI: 10.1144/GSL.SP.1998.135.01.14.

Aparicio M. 1975. Métamorphisme et déformation au contact d'un massif plutonique: l'encaissant du complexe de Quérigut. PhD thesis. Toulouse (France) : Univ. Paul Sabatier.

Arthaud F, Matte P. 1975. Les décrochements tardi-hercyniens du sud-ouest de l'Europe. Géométrie et essai de reconstitution des conditions de la déformation. Tectonophysics 25: 139-171. DOI: 10.1016/0040-1951(75)90014-1.

Arthaud F, Matte P. 1977. Late Paleozoic strike-slip faulting in southern Europe and northern Africa: Result of a right-lateral shear zone between the Appalachians and the Urals. Geol Soc Am Bull 88: 1305-1320. DOI: 10.1130/0016-7606(1977)88<1305: LPSFIS $>2.0 . \mathrm{CO} ; 2$.

Aurejac JB, Gleizes G, Diot H, Bouchez JL. 2004. Le complexe granitique de Quérigut (Pyrénées, France) ré-examiné par la technique de l'ASM : un pluton syntectonique de la transpression dextre hercynienne. Bull Soc Géol Fr 175: 660-661.

Bajolet F, Chardon D, Martinod J, Gapais D, Kermarrec JJ. 2015. Synconvergence flow inside and at the margin of orogenic plateaus: Lithospheric-scale experimental approach. J Geophys Res Solid Earth 120: 6634-6657. DOI: 10.1002/2015JB012110.

Ballèvre M, Bosse V, Ducassou C, Pitra P. 2009. Palaeozoic history of the Armorican Massif: Models for the tectonic evolution of the suture zones. $C R$ Geoscience 341: 174-201. DOI: 10.1016/j. crte.2008.11.009.

Ballèvre M, Catalán JRM, López-Carmona A, Pitra P, Abati J, Fernández RD, et al. 2014. Correlation of the nappe stack in the Ibero-Armorican arc across the Bay of Biscay: a joint FrenchSpanish project. Geol Soc Spec Publ 405: 77-113. DOI: 10.1144/ SP405.13.

Beaumont C, Muñoz JA, Hamilton J, Fullsack P. 2000. Factors controlling the Alpine evolution of the central Pyrenees inferred from a comparison of observations and geodynamical models. $J$ Geophys Res Solid Earth 105: 8121-8145. DOI: 10.1029/ 1999JB900390.

Bosse V, Feraud G, Ruffet G, Ballèvre M, Peucat JJ, De Jong K. 2000. Late Devonian subduction and early-orogenic exhumation of eclogite-facies rocks from the Champtoceaux Complex (Variscan belt, France). Geol J 35: 297-325. DOI: 10.1002/gj.864.

Bouchez JL, Gleizes G. 1995. Two-stage deformation of the MontLouis-Andorra granite pluton (Variscan Pyrenees) inferred from magnetic susceptibility anisotropy. J Geol Soc 152: 669-679. DOI: 10.1144/gsjgs. 152.4.0669.

Bouhallier H, Choukroune P, Ballèvre M. 1991. Évolution structurale de la croûte profonde Hercynienne : exemple du massif de l'Agly (Pyrénées Orientales, France). C R Acad Sci Sér II 312: 647-654.
Burg JP, Van Den Driessche J, Brun JP. 1994. Syn- to post-thickening extension in the Variscan Belt of Western Europe: modes and structural consequences. Géol Fr 3: 33-51.

Bussy F, Hernandez J, Raumer JV. 2000. Bimodal magmatism as a consequence of the post-collisional readjustment of the thickened Variscan continental lithosphere (Aiguilles Rouges-Mont Blanc Massifs, Western Alps). Geol Soc Am Spec Pap 350: 221-233. DOI: $10.1130 / 0-8137-2350-7.221$.

Cagnard F, Durrieu N, Gapais D, Brun JP, Ehlers C. 2006. Crustal thickening and lateral flow during compression of hot lithospheres, with particular reference to Precambrian times. Terra Nova 18: 7278. DOI: $10.1111 / \mathrm{j} .1365-3121.2005 .00665 . x$.

Carreras J. 2001. Zooming on Northern Cap de Creus shear zones. J Struct Geol 23: 1457-1486. DOI: 10.1016/S0191-8141(01)00011-6.

Carreras J, Capella I. 1994. Tectonic levels in the Palaeozoic basement of the Pyrenees: a review and a new interpretation. $J$ Struct Geol 16: 1509-1524. DOI: 10.1016/0191-8141(94)90029-9.

Carreras J, Capella I. 1995. Tectonic levels in the Palaeozoic basement of the Pyrenees- a review and a new interpretation: Reply. J Struct Geol 17: 1493-1495. DOI: 10.1016/0191-8141(95) 00050-N.

Carreras J, Debat P. 1996. Tectonique hercynienne. In Synthèse Géologique et Géophysique Des Pyrénées vol. 1. Orléans (France) : BRGM-ITGE, pp. 501-584.

Carreras J, Druguet E. 2014. Framing the tectonic regime of the NE Iberian Variscan segment. Geol Soc Spec Publ 405: 249-264. DOI: 10.1144/SP405.7.

Carreras J, Druguet E, Griera A, Soldevila J. 2004. Strain and deformation history in a syntectonic pluton. The case of the Roses granodiorite (Cap Creus, Eastern Pyrenees). Geol Soc Spec Publ 224: 307-319.

Chardon D, Gapais D, Cagnard F. 2009. Flow of ultra-hot orogens: a view from the Precambrian, clues for the Phanerozoic. Tectonophysics 477: 105-118. DOI: 10.1016/j.tecto.2009.03.008.

Chardon D, Jayananda M, Peucat JJ. 2011. Lateral constrictional flow of hot orogenic crust: Insights from the Neoarchean of south India, geological and geophysical implications for orogenic plateaux. Geochem Geophys Geosyst 12: Q02005. DOI: 10.1029/ 2010 GC003398.

Choukroune P and the ECORS-Team. 1989. The ECORS Pyrenean deep seismic profile reflection data and the overall structure of an orogenic belt. Tectonics 8: 23-39. DOI: 10.1029/ TC008i001p00023.

Choukroune P. 1992. Tectonic evolution of the Pyrenees. Ann Rev Earth Planet Sci 20: 143-158.

Clin M, Lelong F, Poty B, de la Roche H, Fauré J, Pélissonnier H, et al. 1986. Carte géologique de France à 1/50000, feuille Bagnères-de-Luchon (1084). Orléans (France) : BRGM.

Clin M, Taillefer F, Pouchan P, Muller A. 1989. Notice explicative de la feuille Bagnères-de-Luchon à $1 / 50000$ (1084). Orléans (France) : BRGM.

Couzinié S, Moyen JF, Villaros A, Paquette JL, Scarrow JH, Marignac C. 2014. Temporal relationships between $\mathrm{Mg}-\mathrm{K}$ mafic magmatism and catastrophic melting of the Variscan crust in the southern part of Velay Complex (Massif Central, France). J Geosci 59: 1-18. DOI: $10.3190 /$ jgeosci.155.

Cruden AR, Nasseri MHB, Pysklywec R. 2006. Surface topography and internal strain variation in wide hot orogens from threedimensional analogue and two-dimensional numerical vice models. Geol Soc Spec Publ 253: 79-104. DOI: 10.1144/GSL. SP.2006.253.01.04. 
Davis GH, Coney PJ. 1979. Geologic development of the Cordilleran metamorphic core complexes. Geology 7: 120-124. DOI: 10.1130/ 0091-7613(1979)7<120:GDOTCM>2.0.CO;2.

Debon F, Guitard G. 1996. Carte de synthèse, métamorphisme et plutonisme hercyniens. In: Synthèse Géologique et Géophysique Des Pyrénées vol. 1. Orléans (France) : BRGM-ITGE.

Debon F, Enrique P, Autran A. 1996. Magmatisme hercynien. In: Synthèse Géologique et Géophysique Des Pyrénées vol. 1. Orléans (France) : BRGM-ITGE, pp. 361-499.

Delvolvé JJ, Souquet P, Vachard D, Perret MF, Aguirre P. 1993. Caractérisation d'un bassin d'avant-pays dans le Carbonifère des Pyrénées : faciès, chronologie de la tectonique synsédimentaire. $C$ $R$ Acad Sci. Sér II 316: 959-966.

Denèle Y, Olivier P, Gleizes G, Barbey P. 2007. The Hospitalet gneiss dome (Pyrenees) revisited: lateral flow during Variscan transpression in the middle crust. Terra Nova 19: 445-453. DOI: 10.1111/j.1365-3121.2007.00770.x.

Denèle Y, Olivier P, Gleizes G. 2008. Progressive deformation of a zone of magma transfer in a transpressional regime: The Variscan Mérens shear zone (Pyrenees, France). J Struct Geol 30: 11381149. DOI: $10.1016 /$ j.jsg.2008.05.006.

Denèle Y, Olivier P, Gleizes G, Barbey P. 2009. Decoupling between the middle and upper crust during transpression-related lateral flow: Variscan evolution of the Aston gneiss dome (Pyrenees, France). Tectonophysics 477: 244-261. DOI: 10.1016/j.tecto.2009.04.033.

Denèle Y, Paquette JL, Olivier P, Barbey P. 2012. Permian granites in the Pyrenees: the Aya pluton (Basque Country). Terra Nova 24: 105-113. DOI: 10.1111/j.1365-3121.2011.01043.x.

Denèle Y, Laumonier B, Paquette JL, Olivier P, Gleizes G, Barbey P. 2014. Timing of granite emplacement, crustal flow and gneiss dome formation in the Variscan segment of the Pyrenees. Geol Soc Spec Publ 405: 265-287. DOI: 10.1144/SP405.5.

Déramond J. 1979. Déformation et déplacement des nappes : exemple de la nappe de Gavarnie (Pyrénées Centrales). Doctorat d'État thesis. Toulouse (France): Univ. Paul Sabatier.

Dias R, Ribeiro A, Romão J, Coke C, Moreira N. 2016. A review of the arcuate structures in the Iberian Variscides; constraints and genetic models. Tectonophysics 681: 170-194. DOI: 10.1016/j. tecto.2016.04.011.

Dokka RK, Ross TM, Lu G. 1998. The Trans Mojave-Sierran shear zone and its role in Early Miocene collapse of southwestern North America. Geol Soc Spec Publ 135: 183-202. DOI: 10.1144/GSL. SP.1998.135.01.12.

Druguet E, Castro A, Chichorro M, Pereira MF, Fernández C. 2014. Zircon geochronology of intrusive rocks from Cap de Creus, Eastern Pyrenees. Geol Mag 151: 1095-1114. DOI: 10.1017/ S0016756814000041.

Edel JB, Casini L, Oggiano G, Rossi P, Schulmann K. 2014. Early Permian $90^{\circ}$ clockwise rotation of the Maures-Estérel-CorsicaSardinia block confirmed by new palaeomagnetic data and followed by a Triassic $60^{\circ}$ clockwise rotation. Geol Soc Spec Publ 405: 333-361. DOI: 10.1144/SP405.10.

Engel W. 1984. Migration of Folding and Flysch Sedimentation on the Southern Flank of the Variscan Belt (Montagne Noire, Mouthoumet Massif, Pyrenees). Z Dtsch Geol Ges 135: 279-292.

Esteban JJ, Aranguren A, Cuevas J, Hilario A, Tubía JM, Larionov A, et al. 2015. Is there a time lag between the metamorphism and emplacement of plutons in the Axial Zone of the Pyrenees? Geol Mag 152: 935-941. DOI: 10.1017/S001675681500014X.

Faure M. 1995. Late orogenic carboniferous extensions in the Variscan French Massif Central. Tectonics 14: 132-153. DOI: 10.1029/94TC02021.
Faure M, Bé Mézème E, Cocherie A, Rossi P, Chemenda A, Boutelier D. 2008. Devonian geodynamic evolution of the Variscan Belt, insights from the French Massif Central and Massif Armoricain. Tectonics 27: TC2005. DOI: 10.1029/2007TC002115.

Faure M, Lardeaux JM, Ledru P. 2009. A review of the pre-Permian geology of the Variscan French Massif Central. C R Géoscience 341: 202-213. DOI: 10.1016/j.crte.2008.12.001.

Fernández-Suárez J, Dunning GR, Jenner GA, Gutiérrez-Alonso G. 2000. Variscan collisional magmatism and deformation in NW Iberia: constraints from U-Pb geochronology of granitoids. J Geol Soc 157: 565-576. DOI: 10.1144/jgs.157.3.565.

Franke W. 2014. Topography of the Variscan orogen in Europe: failed-not collapsed. Int $J$ Earth Sci 103: 1471-1499. DOI: 10.1007/s00531-014-1014-9.

Gapais D. 1989. Shear structures within deformed granites mechanical and thermal indicators. Geology 17: 1144-1147.

Gapais D, Balé P, Choukroune P, Cobbold P, Mahjoub Y, Marquer D. 1987. Bulk kinematics from shear zone patterns: some field examples. J Struct Geol 9: 635-646. DOI: 10.1016/0191-8141(87) 90148-9.

Gapais D, Potrel A, Machado N. 2005. Kinematics of long-lasting Paleoproterozoic transpression within the Thompson Nickel Belt, Manitoba, Canada. Tectonics 24: TC3002. DOI: 10.1029/ 2004TC001700.

Gapais D, Brun JP, Gumiaux C, Cagnard F, Ruffet G, Le Carlier de Veslud C. 2015. Extensional tectonics in the Hercynian Armorican belt (France). An overview. Bull Soc Géol Fr 186: 117-129. DOI: 10.2113/gssgfbull.186.2-3.117.

García-Sansegundo J. 1990. Structure of the Paleozoic in the Aran valley, Axial zone, central Pyrenees. Bull Soc Geol Fr 8(VI): 229 239.

García-Sansegundo J. 1992. Estratigrafía y estructura de la Zona Axial pirenaica en la transversal del Valle de Arán y de la Alta Ribagorça. Publicaciones especiales del Boletín Geológico y Minero, ITGE 103: 1-290.

Gébelin A, Brunel M, Monié P, Faure M, Arnaud N. 2007. Transpressional tectonics and Carboniferous magmatism in the Limousin, Massif Central, France: Structural and ${ }^{40} \mathrm{Ar} /{ }^{39} \mathrm{Ar}$ investigations. Tectonics 26: TC2008. DOI: 10.1029/ 2005 TC001822.

Gébelin A, Roger F, Brunel M. 2009. Syntectonic crustal melting and high-grade metamorphism in a transpressional regime, Variscan Massif Central, France. Tectonophysics 477: 229-243. DOI: 10.1016/j.tecto.2009.03.022.

Giacomini F, Braga R, Tiepolo M, Tribuzio R. 2006. New constraints on the origin and age of Variscan eclogitic rocks (Ligurian Alps, Italy). Contrib Mineral Petrol 153: 29-53. DOI: 10.1007/ s00410-006-0131-2.

Gibson RL, Bickle MJ. 1994. Thermobarometric constraints on the conditions of metamorphism in the Canigou massif, Pyrenees: implications for Hercynian geothermal gradients. J Geol Soc 15: 987-997. DOI: 10.1144/gsjgs.151.6.0987.

Gleizes G, Leblanc D, Bouchez JL. 1997. Variscan granites of the Pyrenees revisited: their role as syntectonic markers of the orogen. Terra Nova 9: 38-41. DOI: 10.1046/j.1365-3121.1997.d01-9.x.

Gleizes G, Leblanc D, Santana V, Olivier P, Bouchez JL. 1998a. Sigmoidal structures featuring dextral shear during emplacement of the Hercynian granite complex of Cauterets-Panticosa (Pyrenees). J Struct Geol 20: 1229-1245. DOI: 10.1016/S0191-8141(98) 00060-1.

Gleizes G, Leblanc D, Bouchez JL. 1998b. The main phase of the Hercynian orogeny in the Pyrenees is a dextral transpression. Geol 
Soc Spec Publ 135: 267-273. DOI: 10.1144/GSL. SP.1998.135.01.17.

Gleizes G, Leblanc D, Olivier P, Bouchez J. 2001. Strain partitioning in a pluton during emplacement in transpressional regime: the example of the Néouvielle granite (Pyrenees). Int J Earth Sci 90: 325-340. DOI: 10.1007/s005310000144.

Gleizes G, Crevon G, Asrat A, Barbey P. 2006. Structure, age and mode of emplacement of the Hercynian Bordères-Louron pluton (Central Pyrenees, France). Int J Earth Sci 95: 1039-1052. DOI: 10.1007/s00531-006-0088-4.

Grocott J, McCaffrey KJ, Taylor GK, Tikoff B. 2004. Vertical coupling and decoupling in the lithosphere. Geol Soc Spec Publ 227: $1-7$.

Guitard G, 1964. Un exemple de structure en nappe de style pennique dans la chaîne hercynienne: les gneiss stratoïdes du Canigou (Pyrénées-Orientales). C R Acad Sci Sér D 258: 4597-4599.

Guitard G. Geyssant J, Laumonier B, 1984. Les plissements hercyniens tardifs dans le Paléozoïque inférieur du versant nord du Canigou. $1^{\text {re }}$ partie: analyse géométrique et chronologie des phases superposées. Relations avec le granite de Mont-Louis et le métamorphisme régional. Géol Fr 4: 95-125.

Guitard G, Vielzeuf D, Martinez F. 1996. Métamorphisme hercynien. In Synthèse Géologique et Géophysique Des Pyrénées vol. 1. Orléans (France) : BRGM-ITGE, pp. 501-584.

Guitard G, Laumonier B, Autran A, Bandet Y, Berger GM. 1998. Notice explicative, Carte géologique de la France à 1/50000, feuille Prades (1095). Orléans (France) : BRGM.

Gutiérrez-Alonso G, Fernández-Suárez J, Jeffries TE, Johnston ST, Pastor-Galán D, Murphy JB, et al. 2011a. Diachronous postorogenic magmatism within a developing orocline in Iberia, European Variscides. Tectonics 30: TC5008. DOI: 10.1029/ 2010 TC002845.

Gutiérrez-Alonso G, Murphy JB, Fernández-Suárez J, Weil AB, Franco MP, Gonzalo JC. 2011b. Lithospheric delamination in the core of Pangea: Sm-Nd insights from the Iberian mantle. Geology 39: 155-158. DOI: 10.1130/G31468.1.

Gutiérrez-Alonso G, Johnston ST, Weil AB, Pastor-Galán D, Fernández-Suárez J. 2012. Buckling an orogen: The Cantabrian Orocline. GSA Today 22: 4-9. DOI: 10.1130/GSATG141A.1.

Hilario-Orús A. 2004. Relación entre magmatismo y deformación en la transversal de Benasque a Luchon (Zona Axial del Pirineo). PhD thesis. Spain: Univ. Pais Vasco.

Holdsworth RE, Strachan RA. 1991. Interlinked system of ductile strike slip and thrusting formed by Caledonian sinistral transpression in northeastern Greenland. Geology 19: 510-513.

Holdsworth RE, Tavarnelli E, Clegg P, Pinheiro RVL, Jones RR, McCaffrey KJW. 2002. Domainal deformation patterns and strain partitioning during transpression: an example from the Southern Uplands terrane, Scotland. J Geol Soc 159: 401-415. DOI: 10.1144/0016-764901-123.

Kilzi MA, Grégoire M, Bosse V, Benoît M, Driouch Y, de Saint Blanquat $\mathrm{M}$, et al. 2016. Geochemistry and zircon U-Pb geochronology of the ultramafic and mafic rocks emplaced within the anatectic series of the Variscan Pyrenees: The example of the Gavarnie-Heas dome (France). C R Géoscience 348: 107-115. DOI: $10.1016 /$ j.crte.2015.06.014.

Kleinsmiede WFJ. 1960. Geology of the Val de Arán. Leidse Geol Meded 25: 129-245.

Kretz R. 1983. Symbols for rock-forming minerals. Am Mineral 68: 277-279.

Kriegsman LM, Aerden DGAM, Bakker RJ, den Brok SWJ, Schutjens PMTM. 1989. Variscan tectonometamorphic evolution of the eastern Lys-Caillaouas massif, Central Pyrenees - evidence for late orogenic extension prior to peak metamorphism. Geol Mijnb 68: 323-333.

Lardeaux JM, Schulmann K, Faure M, Janoušek V, Lexa O, Skrzypek E, et al. 2014. The Moldanubian Zone in the French Massif Central, Vosges/Schwarzwald and Bohemian Massif revisited: differences and similarities. Geol Soc Spec Publ 405: 7-44. DOI: 10.1144/ SP405.14.

Laurent O, Couzinié S, Zeh A, Vanderhaeghe O, Moyen JF, Villaros A, et al. 2017. Protracted, coeval crust and mantle melting during Variscan late-orogenic evolution: $\mathrm{U}-\mathrm{Pb}$ dating in the eastern French Massif Central. Int J Earth Sci 106: 421-451. DOI: 10.1007/s00531-016-1434-9.

Le Pourhiet L, Huet B, May DA, Labrousse L, Jolivet L. 2012. Kinematic interpretation of the 3D shapes of metamorphic core complexes. Geochem Geophys Geosyst 13: Q09002. DOI: 10.1029/2012GC004271.

Lemirre B, Duchene S, Saint-Blanquat M, Poujol M. 2016. État thermique de la croûte varisque dans le massif nord-pyrénéen du Saint Barthélémy. Caen (France) : 25th Earth Science Meeting.

Lister GS, Davis GA. 1989. The origin of metamorphic core complexes and detachment faults formed during Tertiary continental extension in the northern Colorado River region, U.S.A. J Struct Geol 11: 65-94.

Majesté-Menjoulas C. 1979. Évolution alpine d'un segment de chaîne varisque: Nappe de Gavarnie, chevauchement Cinq-MontsGentiane (Pyrénées centrales et occidentales), Doctorat d'État thesis. Toulouse (France) : Univ. Paul Sabatier.

Malavieille J. 1993. Late Orogenic extension in mountain belts: Insights from the Basin and Range and the Late Paleozoic Variscan Belt. Tectonics 12: 1115-1130. DOI: 10.1029/93TC01129.

Marre J, 1973. Le complexe éruptif de Quérigut. Pétrologie, structurologie, cinématique de mise en place. Doctorat d'Etat thesis. Toulouse (France) : Univ. Paul Sabatier.

Martínez-Catalán JR. 1990. A non-cylindrical model for the northwest Iberian allochthonous terranes and their equivalents in the Hercynian belt of Western Europe. Tectonophysics 179: 253 272. DOI: 10.1016/0040-1951(90)90293-H.

Martínez-Catalán JR. 2011. Are the oroclines of the Variscan belt related to late Variscan strike-slip tectonics? Terra Nova 23: 241247. DOI: 10.1111/j.1365-3121.2011.01005.x.

Martínez-Catalán JR, Arenas R, Abati J, Martínez SS, García FD, Suárez JF, et al. 2009. A rootless suture and the loss of the roots of a mountain chain: The Variscan belt of NW Iberia. C R Geoscience 341: 114-126. DOI: 10.1016/j.crte.2008.11.004.

Martínez-Catalán JR, Pascual FJR, Montes AD, Fernández RD, Barreiro JG, Silva ÍDD, et al. 2014. The late Variscan HT/LP metamorphic event in NW and Central Iberia: relationships to crustal thickening, extension, orocline development and crustal evolution. Geol Soc Spec Publ 405: 225-247. DOI: 10.1144/ SP405.1.

Matte P. 1986. Tectonics and plate tectonics model for the Variscan belt of Europe. Tectonophysics 126: 329-374. DOI: 10.1016/ 0040-1951(86)90237-4.

Matte P. 2002. Les plis hercyniens kilométriques couchés vers l'ouest-sudouest dans la région du pic du Midi d'Ossau-col du Somport (zone axiale des Pyrénées occidentales). C R Géoscience 334: 773-779.

Matte P. 2007. Variscan thrust nappes, detachments, and strike-slip faults in the French Massif Central: Interpretation of the lineations. Geol Soc Am Mem 200: 391-402. DOI: 10.1130/2007.1200(20).

Matte P, Ribeiro A. 1975. Forme et orientation de l'ellipsoïde de déformation dans la virgation hercynienne de Galice. Relations avec le plissement et hypothèses sur la genèse de l'arc ibéroarmoricain. C R Acad Sci Sér D 280: 2825-2828. 
Messaoudi H. 1990. Le complexe plutonique de Millas (Pyrénées Orientales) : pétrologie, géochimie, structurologie et cinématique de mise en place. PhD thesis. Toulouse (France): Univ. Paul Sabatier.

Mey PHW. 1967. The geology of the upper Ribagorzana and Baliera valleys, central Pyrenees, Spain. Leidse Geol Meded 41: 153-220.

Mey PHW. 1968. The geology of the upper Ribagorzana and Tor Valleys, Central Pyrenees, Spain sheet 8, 1:50 000. Leidse Geol Meded 41: 229-292.

Mezger JE. 2005. Comparison of the western Aston-Hospitalet and the Bossòst domes: evidence for polymetamorphism and its implications for the Variscan tectonic evolution of the Axial Zone of the Pyrenees. J Virtual Explor 19: 6. DOI: 10.3809/ jvirtex.2005.00122.

Mezger JE. 2009. Transpressional tectonic setting during the main Variscan deformation: evidence from four structural levels in the Bossòst and Aston-Hospitalet mantled gneiss domes, central Axial Zone, Pyrenees. Bull Soc Geol Fr 180: 199-207. DOI: 10.2113/ gssgfbull.180.3.199.

Mezger JE. 2010. Cadomian, Ordovician and Variscan igneous events preserved in gneiss domes of the Central Pyrenean Axial Zone. TSK 13 Conference Abstracts and Field Guide 40.

Mezger JE, Passchier CW. 2003. Polymetamorphism and ductile deformation of staurolite-cordierite schist of the Bossòst dome: indication for Variscan extension in the Axial Zone of the central Pyrenees. Geol Mag 140: 595-612. DOI: 10.1017/ S0016756803008112.

Mezger JE, Passchier CW, Régnier JL. 2004. Metastable staurolitecordierite assemblage of the Bossòst dome: Late Variscan decompression and polyphase metamorphism in the Axial Zone of the central Pyrenees. $C R$ Géoscience 336: 827-837. DOI: 10.1016/j.crte.2003.12.024.

Mezger JE, Gerdes A. 2016. Early Variscan (Visean) granites in the core of central Pyrenean gneiss domes: implications from laser ablation U-Pb and Th- $\mathrm{Pb}$ studies. Gondwana Res 29: 181-198. DOI: $10.1016 /$ j.gr.2014.11.010.

Mezger JE, Régnier JL. 2016. Stable staurolite-cordierite assemblages in K-poor metapelitic schists in Aston and Hospitalet gneiss domes of the central Pyrenees (France, Andorra). J Metam Geol 34: 167-190. DOI: $10.1111 /$ jmg. 12177.

Mirouse R. 1962. Recherches géologiques dans la partie occidentale de la Zone primaire axiale des Pyrénées. Doctorat d'État thesis. Toulouse (France) : Univ. Paul Sabatier.

Müller J, Roger P. 1977. L'Évolution structurale des Pyrénées (domaine central et occidental). Le segment hercynien, la chaîne de fond alpine. Géol Alpine 2: 1-191.

Muñoz JA. Evolution of a continental collision belt: ECORSPyrenees crustal balanced cross-section. In: McClay KR, ed. Thrust Tectonics. London: Chapman \& Hall, 1992, pp. 235-246. DOI: 10.1007/978-94-011-3066-0_21.

Ordóñez Casado B, Gebauer D, Schäfer HJ, Ibarguchi JIG, Peucat JJ. 2001. A single Devonian subduction event for the HP/HT metamorphism of the Cabo Ortegal complex within the Iberian Massif. Tectonophysics 332: 359-385. DOI: 10.1016/S0040-1951 (00)00210-9.

Paquet J, Mansy JL. 1991. La structure de l'Est des Pyrénées (transversales du massif de l'Agly) : un exemple d'amincissement crustal. C R Acad Sci Sér 2 312: 913-919.

Paquette JL, Menot RP, Peucat JJ. 1989. REE, Sm-Nd and U-Pb zircon study of eclogites from the Alpine External Massifs (Western Alps): evidence for crustal contamination. Earth Planet Sci Lett 96: 181-198. DOI: 10.1016/0012-821X(89)90131-3.
Pastor-Galán D, Gutiérrez-Alonso G, Weil AB. 2011. Orocline timing through joint analysis: Insights from the Ibero-Armorican Arc. Tectonophysics 507: 31-46. DOI: 10.1016/j.tecto.2011.05.005.

Pastor-Galán D, Dekkers MJ, Gutiérrez-Alonso G, Brouwer D, Groenewegen T, Krijgsman W, et al. 2016. Paleomagnetism of the Central Iberian curve's putative hinge: Too many oroclines in the Iberian Variscides. Gondwana Res 39: 96-113. DOI: 10.1016/j. gr.2016.06.016.

Pouget P. 1991. Hercynian tectonometamorphic evolution of the Bosost dome (French-Spanish central Pyrenees). J Geol Soc 148: 299-314. DOI: 10.1144/gsjgs.148.2.0299.

Poujol M, Pitra P, Van Den Driessche J, Tartèse R, Ruffet G, Paquette JL, et al. 2017. Two-stage partial melting during Variscan extensional tectonics (Montagne Noire, France). Int J Earth Sci 106: 477-500.

Rey PF, Burg JP, Casey M. 1997. The Scandinavian Caledonides and their relationship to the Variscan belt. Geol Soc Spec Publ 121: 179-200.

Rey PF, Teyssier C, Whitney DL. 2010. Limit of channel flow in orogenic plateaux. Lithosphere 2: 328-332. DOI: 10.1130/L114.1.

Rey PF, Mondy L, Duclaux G, Teyssier C, Whitney DL, Bocher M, et al. 2017. The origin of contractional structures in extensional gneiss domes. Geology 45: 263-266.

Roberts MP, Pin C, Clemens JD, Paquette JL. 2000. Petrogenesis of Mafic to Felsic Plutonic Rock Associations: the Calc-alkaline Quérigut Complex, French Pyrenees. J Petrol 41: 809-844. DOI: 10.1093/petrology/41.6.809.

Rodríguez J, Cosca MA, Gil Ibarguchi JI, Dallmeyer RD. 2003. Strain partitioning and preservation of ${ }^{40} \mathrm{Ar} /{ }^{39} \mathrm{Ar}$ ages during Variscan exhumation of a subducted crust (Malpica-Tui complex, NW Spain). Lithos 70: 111-139. DOI: 10.1016/S0024-4937(03)00095-1.

Roger F, Matte P. 2005. Early Variscan HP metamorphism in the western Iberian Allochthon-A $390 \mathrm{Ma} \mathrm{U}-\mathrm{Pb}$ age for the Bragança eclogite (NW Portugal). Int J Earth Sci 94: 173-179. DOI: 10.1007/s00531-005-0466-3.

Roger F, Teyssier C, Respaut JP, Rey PF, Jolivet M, Whitney DL, et al. 2015. Timing of formation and exhumation of the Montagne Noire double dome, French Massif Central. Tectonophysics 640: 53-69. DOI: 10.1016/j.tecto.2014.12.002.

Román-Berdiel T, Casas AM, Oliva-Urcia B, Pueyo EL, Rillo C. 2004. The main Variscan deformation event in the Pyrenees: new data from the structural study of the Bielsa granite. J Struct Geol 26: 659-677. DOI: 10.1016/j.jsg.2003.09.001.

Román-Berdiel T, Casas AM, Oliva-Urcia B, Pueyo EL, Liesa C, Soto R. 2006. The Variscan Millares granite (central Pyrenees): Pluton emplacement in a $\mathrm{T}$ fracture of a dextral shear zone. Geodin Acta 19: 197-211. DOI: 10.3166/ga.19.197-211.

Rubio Pascual FJ, Arenas R, Martínez Catalán JR, Rodríguez Fernández LR, Wijbrans JR. 2013. Thickening and exhumation of the Variscan roots in the Iberian Central System: Tectonothermal processes and ${ }^{40} \mathrm{Ar} /{ }^{39} \mathrm{Ar}$ ages. Tectonophysics 587: 207-221. DOI: 10.1016/j.tecto.2012.10.005.

Saint-Blanquat M. (de). 1993. La faille normale du massif du Saint Barthélémy. Évolution hercynienne des massifs nord-pyrénéens catazonaux considérée du point de vue de leur histoire thermique. Geodin Acta 6: 59-77.

Sandiford M, Powell R. 1991. Some remarks on high-temperaturelow-pressure metamorphism in convergent orogens. J Metam Geol 9: 333-340. DOI: 10.1111/j.1525-1314.1991.tb00527.x.

Séguret M, Proust F. 1968. Tectonique hercynienne des Pyrénées centrales : signification des schistosités redressées, chronologie des déformations. C R Acad Sci Sér D 266: 984-987. 
Sitter LU (de), Zwart HJ. 1960. Tectonic development in supra and infra-structures of a mountain chain. Proc 21st Int Geol Congr Copenhagen 18: 248-256.

Soula JC. 1982. Characteristics and mode of emplacement of gneiss domes and plutonic domes in central-eastern Pyrenees. J Struct Geol 4: 313-342.

Soula JC, Debat P, Deramond J, Pouget P. 1986a. A dynamic model of the structural evolution of the Hercynian Pyrenees. Tectonophysics 129: 29-51.

Soula JC, Debat P, Déramond J, Guchereau JY, Lamouroux C, Pouget P, et al. 1986b. Évolution structurale des ensembles métamorphiques, des gneiss et des granitoïdes dans les Pyrénées centrales. Bull Soc Géol Fr 8: 79-93.

Speksnijder A. 1987. The detection and significance of early deformation in the southern Variscan Pyrenees, Spain; implications for regional Paleozoic structural evolution. Geol Rundsch 76: 451476. DOI: 10.1007/BF01821086.

Thompson AB, England PC. 1984. Pressure-Temperature-Time Paths of Regional Metamorphism II. Their Inference and Interpretation using Mineral Assemblages in Metamorphic Rocks. J Petrol 25: 929-955. DOI: 10.1093/petrology/ 25.4.929.

Tikoff B, Teyssier C. 1994. Strain modeling of displacement-field partitioning in transpressional orogens. J Struct Geol 16: 1575-1588.

Tikoff B, Teyssier C, Waters C. 2002. Clutch tectonics and the partial attachment of lithospheric layers. EGU Stephan Mueller Spec Publ Ser 1: 57-73.

Tikoff B, Russo R, Teyssier C, Tommasi A. 2004. Mantle-driven deformation of orogenic zones and clutch tectonics. Geol Soc London Spec Publ 227: 41-64.

Valero J, 1974. Géologie Structurale du Paléozoïque de la région de Panticosa - Province de Huesca (Espagne). PhD thesis. Bordeaux (France) : Univ. de Bordeaux.

Valle de Lersundi J, Adler RE, de Boer HU, Jordan H, Klarr K, Krausse HF, et al. 1972. Mapa geologico de Espana (1/50 000), Valcarlos (91). Madrid, Spain: IGME.
Van den Eeckhout B, Zwart HJ. 1988. Hercynian crustal-scale extensional shear zone in the Pyrenees. Geology 16: 135-138. DOI: 10.1130/0091-7613(1988)016<0135:HCSESZ>2.3.CO;2.

Van der Voo R. 2004. Paleomagnetism, Oroclines, and Growth of the Continental Crust. GSA Today 14: 4-9. DOI: 10.1130/1052-5173 (2004)014<4:POAGOT > 2.0.CO;2.

Vanderhaeghe O, Teyssier C. 2001. Partial melting and flow of orogens. Tectonophysics 342: 451-472. DOI: 10.1016/S0040-1951 (01)00175-5.

Van Lichtervelde M, Grand'Homme A, de Saint-Blanquat M, Olivier P, Gerdes A, Paquette JL, et al. 2017. U-Pb geochronology on zircon and columbite-group minerals of the Cap de Creus pegmatites, NE Spain. Mineral Petrol 111: 1-21.

Vilà M, Pin C, Liesa M, Enrique P. 2007. LP-HT metamorphism in a late orogenic transpressional setting, Albera Massif, NE Iberia: implications for the geodynamic evolution of the Variscan Pyrenees. J Metam Geol 25: 321-347. DOI: 10.1111/ j.1525-1314.2007.00698.x.

Villalobos Vilches L, del Valle de Lersundi J. 1973. Memoria explicativa, Mapa geologico de Espana (1/50 000), Sumbilla (90). Madrid (Spain): IGME.

Vissers RLM. 1992. Variscan extension in the Pyrenees. Tectonics 11: 1369-1384. DOI: 10.1029/92TC00823.

Weil A, Gutiérrez-alonso G, Conan J. 2010. New time constraints on lithospheric-scale oroclinal bending of the Ibero-Armorican Arc: a palaeomagnetic study of earliest Permian rocks from Iberia. $J$ Geol Soc 167: 127-143. DOI: 10.1144/0016-76492009-002.

Wickham SM, Oxburgh ER. 1985. Continental rifts as a setting for regional metamorphism. Nature 318: 330-333.

Wickham SM, Oxburgh ER. 1986. A rifted tectonic setting for Hercynian high-thermal gradient metamorphism in the Pyrenees. Tectonophysics 129: 53-69.

Zwart HJ. 1979. The geology of the Central Pyrenees. Leidse Geol Meded 50: 1-74.

Zwart HJ. 1986. The Variscan geology of the Pyrenees. Tectonophysics 129: 9-27.

Cite this article as: Cochelin B, Chardon D, Denèle Y, Gumiaux C, Le Bayon B. 2017. Vertical strain partitioning in hot Variscan crust: Synconvergence escape of the Pyrenees in the Iberian-Armorican syntax, Bull. Soc. géol. Fr. 188: 39. 